\title{
من ملامح اللأت وصورة الآخر \\ في نماذج من شعر(زاهي وهبي)
}

From the features of the self

In Poetry (Zahi Wahbi) and the image of the other'

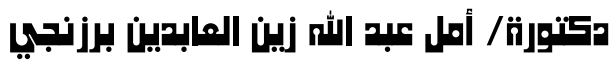

أستاذ الأدب والنقد الحديث المشارك بقسم اللغة العربية

كلية الآداب و العلوم الإنسانية - جامعة طيبة

\section{|المستخلص}

يتتاول هذا البحث نماذج من شعر (زاهي وهبي) للكثف عن ملامح الذات و علاقتها بالآخر في صوره المختلفة، و الوقوف على عمق وإثكالية هذه العلاقة؛ بما

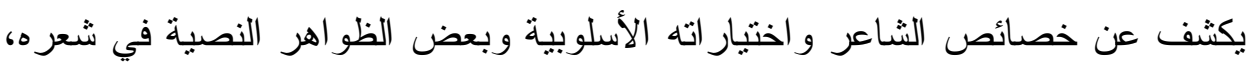
ويحدد توجهاته الذاتية والموضوعية في تكوينه الذاتي لشخصيته بأبعادها الفكرية

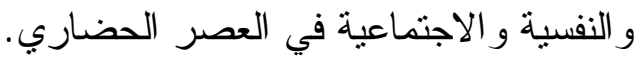

وقد جمعت الدراسة بين المنهج النفسي و آليات المنحى الوصفي و التحليلي لمعالجة

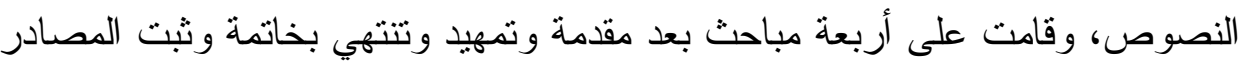
و المر اجع، و المباحث كالآتي:

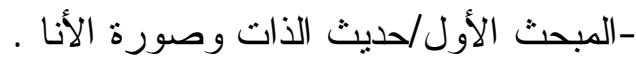

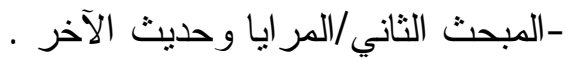
-المبحث الثالث/الذات و المر أة . -المبحث الر ابع/الذات و الطبيعة . و انتهت الدارسة إلى نتائج أبرز ها:

-تضضح صورة الأنا عند (ز اهي وهبي)من خلال صور الآخر القريب أو البعيد، كالمر أة

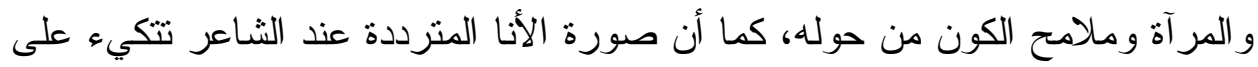

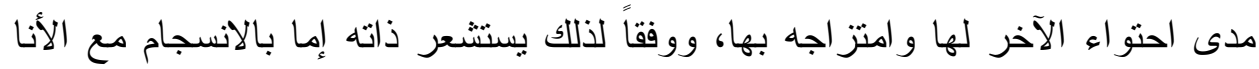

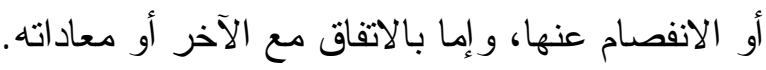


-الآخر يسهم بدور كبير في فهمنا للمعتقدات و القيم والفلسفة والجمال و الهوية الذاتية

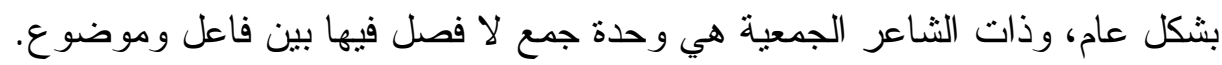
-التجربة الناضجة للشاعر (زاهي وهبي)هي الدافع الأكبر للاتساع و العمق اللفظي

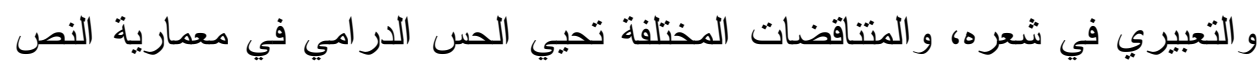
لايه. -اتصل حوار الثاعر في مختلف النصوص بحوار الحضار ات وتاريخ وتزاث الأمم، ومزج فيه بين الماضي و الحاضر من خلال فلسفته الخاصة معبر اً عن ثورته الإبداعية.

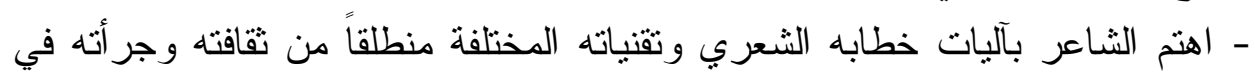
تكوينها وتوظيفها لتعرية الذات وتعقيدات علاقتها بالأنا و الآخر، فاستخدم مستويات مناته

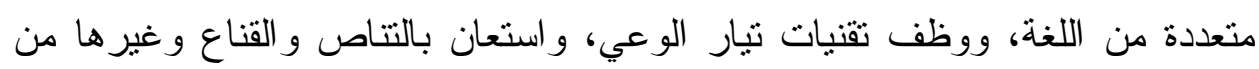

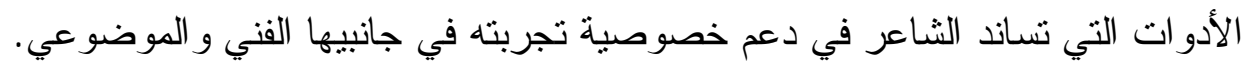
*الكلمات المفتاحية:الثاعر (ز اهي وهبي)، شعر حديث، صورة الأنا، صورة الآخر . 


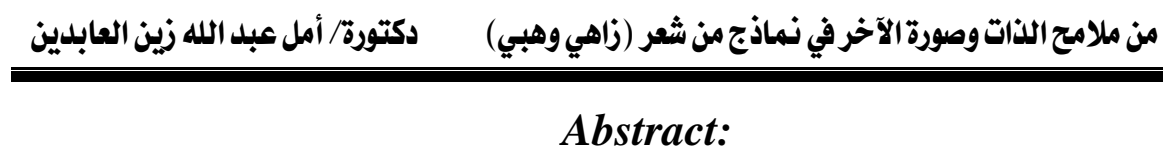

This research deals with models of the poetry (Zahi Wahbi) to reveal the features of the self and its relationship with the other in its various forms, and to identify the depth and problematic of this relationship; And psychological and social in the civilized age.

The study combines the psychological methodology with the descriptive and analytical-oriented mechanisms for text processing. It was based on four topics after introduction, preparation and ending with a conclusion and proven sources and references, a topics as follows:

-First topic: Self-talk and the image of the ego.

-Second topic: Mirrors and other talk.

-Third topic: Self and women.

-Fourth topic: Self and nature.

The study concludes with the following results:

- The image of the ego when (Zahi Wahbi) through the images of the other near or far, such as women and women and the features of the universe around him, and the image of the hesitant ego at the poet leaning on the extent of the containment and mixing them, and accordingly senses himself either in harmony with the ego or disconnect from it, Either in agreement with the other or hostile.

- The other contributes greatly to our understanding of beliefs, values, philosophy, beauty and self-identity in general, and the poet's collective association is an indivisible unity between an actor and a subject.

- The mature experience of the poet (Zahi Wahbi) is the greatest motivation for the breadth and depth of verbal and expressive in his poetry, and the various contradictions revive the dramatic sense in the architecture of the text. 
- The dialogue of the poet in various texts related to the dialogue of civilizations and the history and heritage of nations, mixing it between past and present through his own philosophy expressing his creative revolution.

- The poet was interested in the mechanisms of his poetic discourse and his various techniques, based on his culture and daring to form and employ them to expose oneself and the complexities of their relationship with the ego and the other ,He used multiple levels of language, employed techniques of the stream of consciousness, and used eavesdropping, mask and other tools that support the poet in supporting the specificity of his experience in both artistic and objective aspects.

*Key words:

The poet(Zahi Wahbi), modern poetry, the image of the ego, the image of the other. 


\section{من ملامح الذاتوصورة الآخر في نماذج من شعر (زاهي وهبي) دكتورة/ أمل عبل الله زين العابلين \\ مقدمة}

الحمد لله تعالى وأزكى الصلوات على من أُمر بالقر اءة في أول الوحي فتعلم ما لم

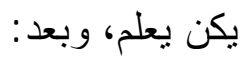

ما من شك في كون الذات أعمق نقطة في تكوين الإنسان و أثند مساحاته تضخماً

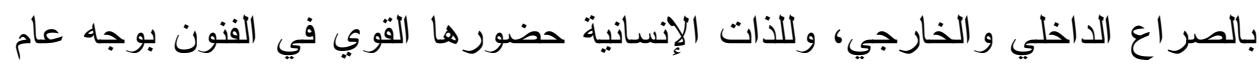

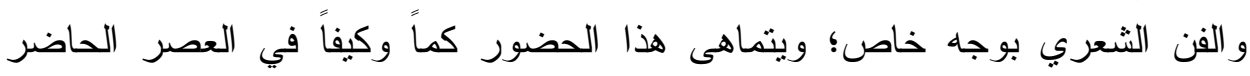

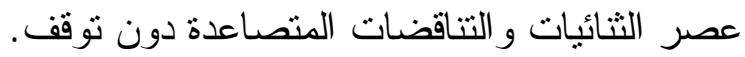
إن محاولات الذات التكوينية للحضور في النص الثعري ما هي إلى مخرجاً للحضور الأكبر في العالم ككل، إذ تفضي أي محاولة للنظر في منظومتها العلائقية

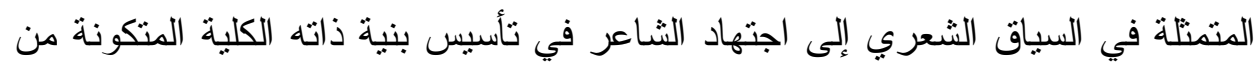
تداخلات وتفاعلات متشابكة مع الآخر وفي وقت لا نز ال تتعارك فيه مع حقيقتها

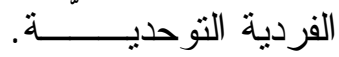
وتقوم هذه الدراسة بمحاولة استجلاء أهم ملامح التعالق بين الذات و الآخر من حولها و أثنكاله المختلفة وتأثير كل منهما في الآخر في العمل الثعري وفي بعدين

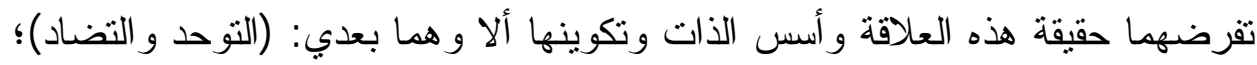

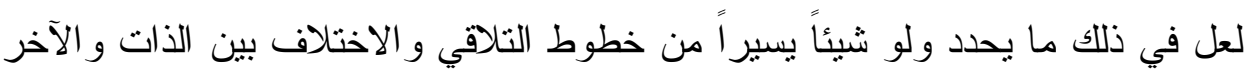

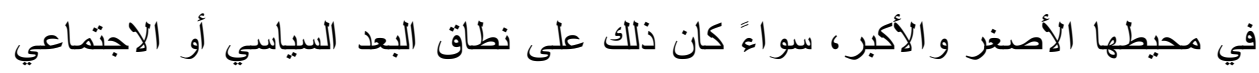
أو الثقافي، والكثف عن بعض ملامح البناء المعرفي لتلك العلاقة و الديناميكية المرئية وغير المرئية -قد تبدو كذلك - التي تتفاعل مع بنية النص وخصوصيته وطموحات

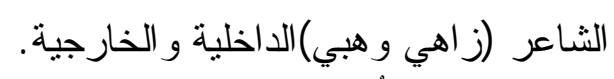

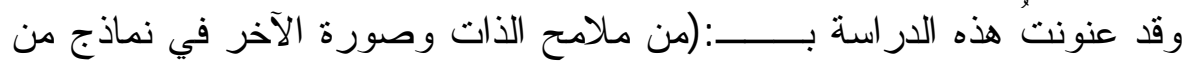

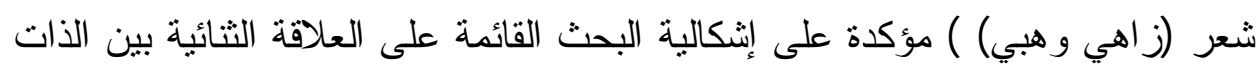
و الآخر في التجربة الثعرية وما تورثه هذه العلاقة لثقافة الذات عامة ولثة ولأدبها خاصة

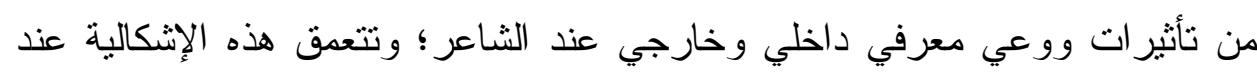

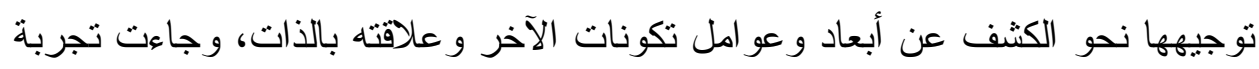

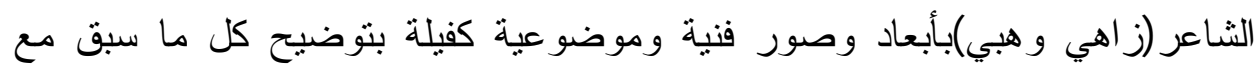


خصوصية هذه التجربة بما يتقق مع المؤثرات الداخلية والخارجية لشخصية الثاعر من شتى جو انبها.

وقد اقتضت طبىعة الموضوع مقاربة وصفىة تحلىلىة تأخذ من المنحى

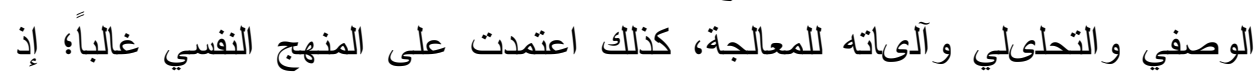
تهدف هذه الدر اسة للكثف عن التجليات الموضوعية و السمات الفنية و الثكلية و التقنيات التي تثير إلى حد بعيد إلى عمق العلاقة بين الذات و الآخر عند الثاعر و التأثنير المتبادل المستمر بين قطبي شخصيته(الذات و الآخر )، ودلالات هذه العلاقة في موروثه الأدبي و الاجتماعي و الفكري.

وتقوم هذه الدراسة على أربعة مباحث مسبوقة بفهرس للمحتويات وملخص

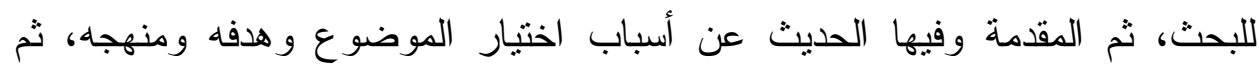
التمهيد وفيه قسمين :في القسم الأول: مصطلح الذات والآخر، وفي القسم الثاني

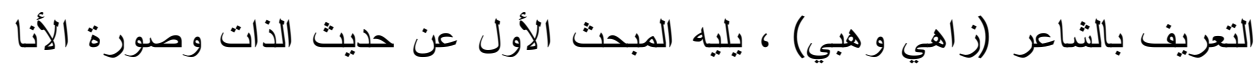

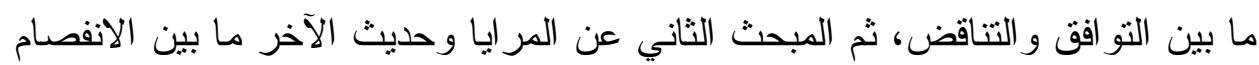

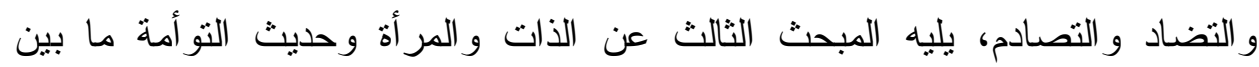
التو افق و التعاضد و التأييد، ثم المبحث الر ابع عن الذات و الطبيعة وحديث الكون الأكبر

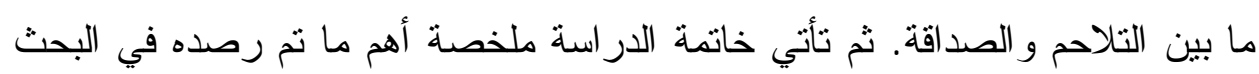
من نتائج ، تليها قائمة المصادر و المر اجع. 


\section{من ملامح الذاتوصورة الآخر في نماذج من شعر (زاهي وهبي) دكتورة/ أمل عبل الله زين العابلين

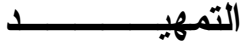

\section{القسم الأول: مصطلح الأت والآخر}

قدم علماء النفس و الفلاسفة دراسات حول سيكولوجية الذات و علاقتها التقاعلية اللازمة بالآخر كونهما مولودان معاً؛ وتظهر أهمية هذه الدر اسات ونتائجها في البحوث

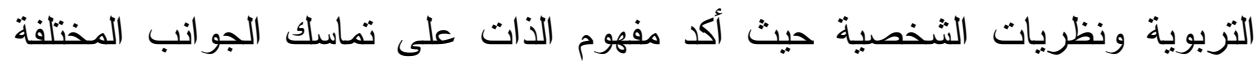
للشخصية ومنحها الخصوصية وتنظيم علاقتها بالعالم الخارجي ومكتسباتها وخبر اتها

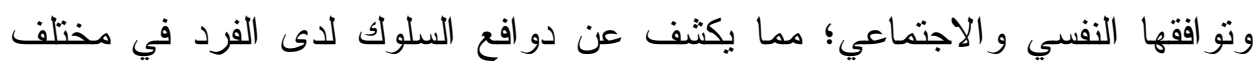
النشاطات الجسدية و الفكرية. وفي اللغة: الذات هي الحقيقة و الخاصية، وتأني بمعنى صاحب"(1)، وفي

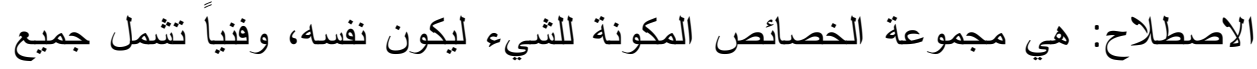

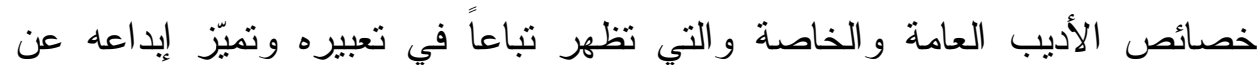

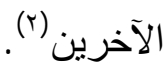

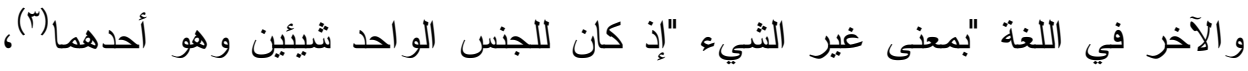

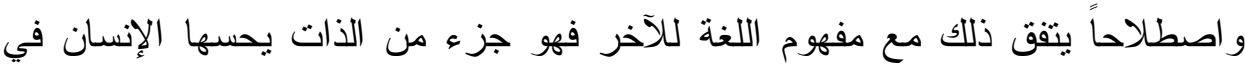
المحيطين به (؛)، ويمكن التعبير عنه بكونه مجموعة الخصائص الفكرية و السلوكية و النفسية و الاجتماعية للجماعة من منظور الفرد وكما ير اها هو (0).

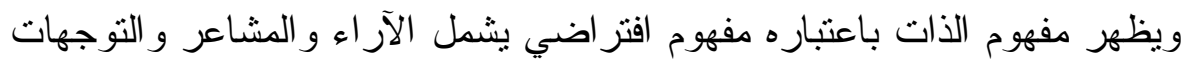

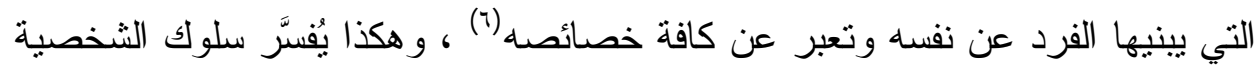
من خلال معرفة مكنونات الذات وهي في كل ذلك مؤثزة في البيئة المحيطة ومتأثزة بها (v)

أما الآخر فله مفهوم لا ينفصل عن مفهوم الذات منها ينشأ ويتبادلان التأثز

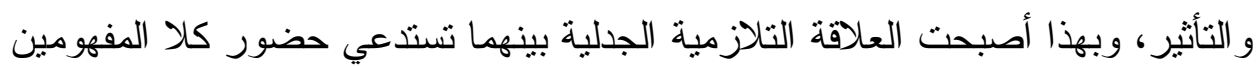
معاً في أي استخدام؛ بل يمكن اعتبار مفهوم الآخر وسيلة لتقويم الذات كما بيّن

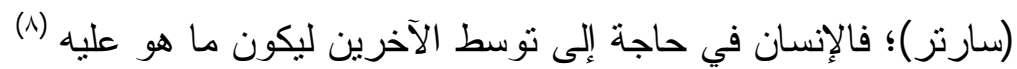

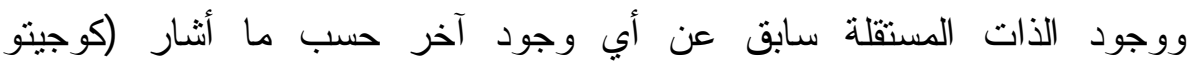

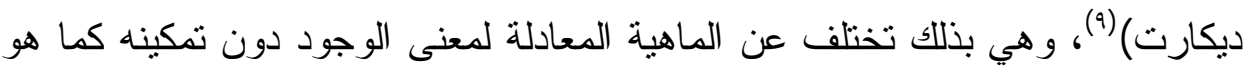
الحال فيما يخص الذات، وتباعاً يصبح كل وجود ليس من حيز الذات هو آخر بالنسبة 
لها، سواءً كان من المحسوسات أو المعنويات، من الأثخاص أو من بقية الأثياء في لئي

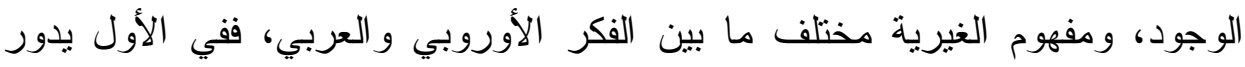

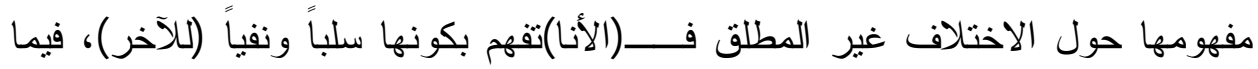

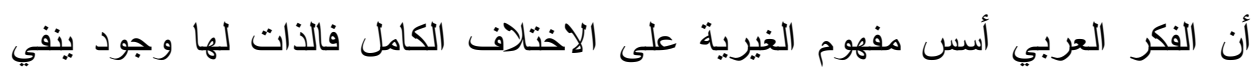

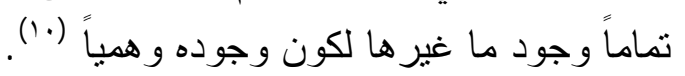
ويرى بعض الفلاسفة أن الذات غير عادلة في علاقدانها بالآخر بسبيين: اعتبار

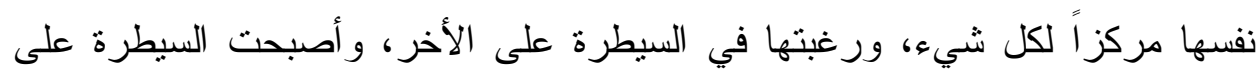

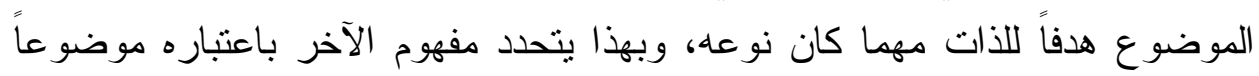

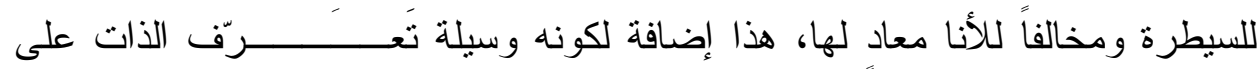

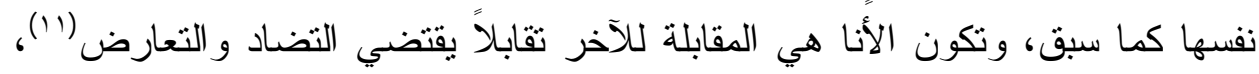

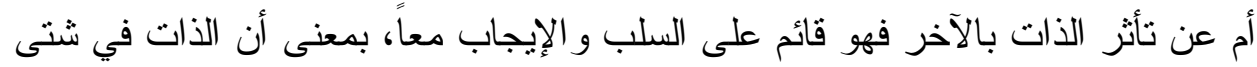

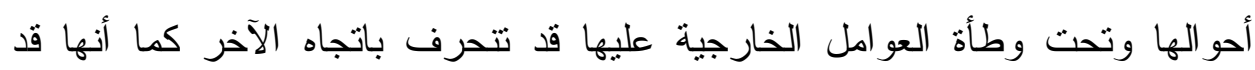

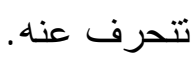
ومفهوم الذات لاى الفرد يتشكل عبر مر احل حياته المختلفة لا سيما سني الطفولة

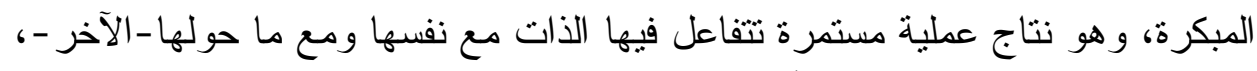

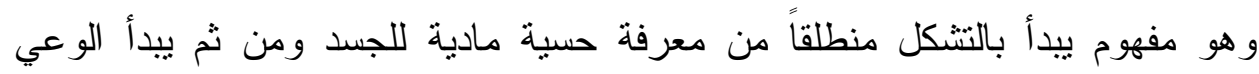

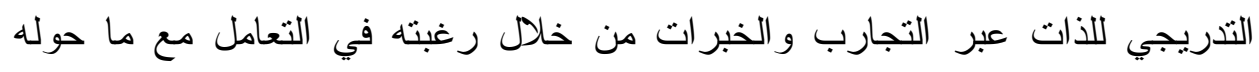

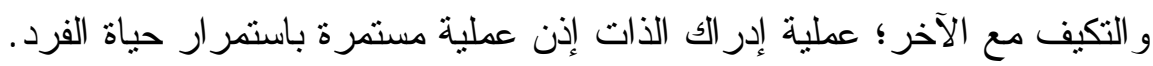

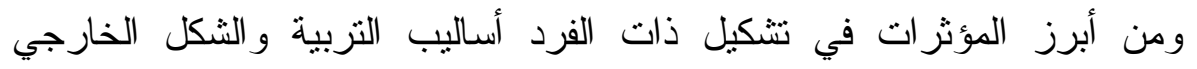

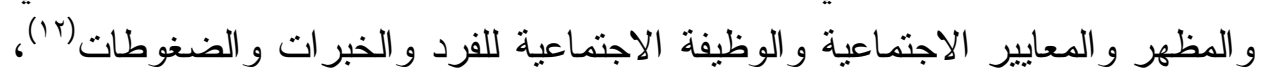

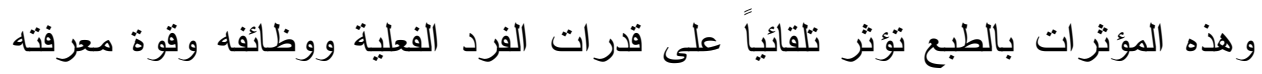

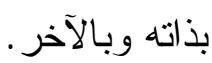

ومن المهم الإثشارة إلى أهم الأبعاد لدفهوم الذات ومنها إلى أبعاد مفهوم الآخر كي

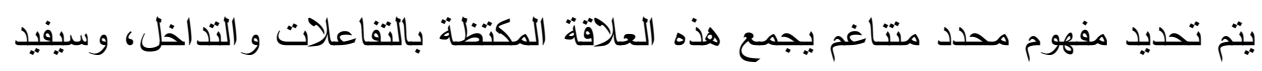

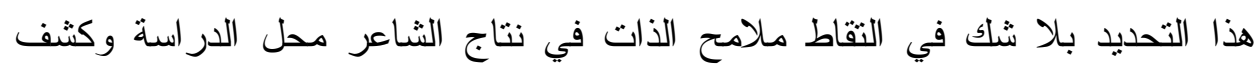

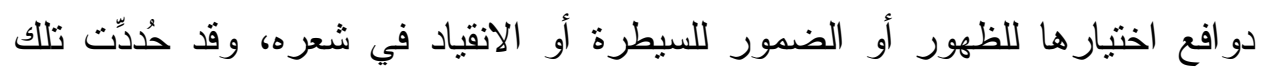

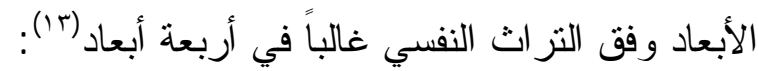




\section{من ملامح الذات وصورة الآخر في نماذج من شعر (زاهي وهبي) دكتورة/ أمل عبد الله زين العابدين}

-مفهوم الذات المدركِ : وهو المفهوم الأساسي لصورة الذات قبل أن يشكلها الفرد وفق رغباته، فهي هنا على حقبقتها في كافة الملامح الخارجية و الداخلية، المادية و المعنوية. -مفهوم الذات المؤقت:و هو مفهوم يتحقق وفق المواقف التي يمر بها الفرد فيكون

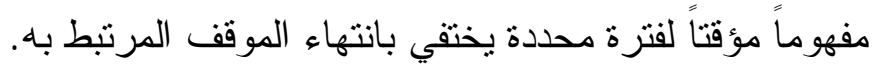

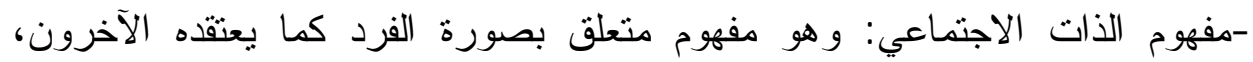
و الناتجة عن أثنكال تعامله معهم.

و وفهوم الذات المثالي: ويرتبط هذا المفهوم بالصورة التي يتمنى الفرد أن يكون عليها وتصور اته حول طريقة تحقيقها (؛ ( ). أما أبعاد مفهوم الآخر فليس من السهل تحديدها؛ إذ هي تطلق من قبل الذات على في

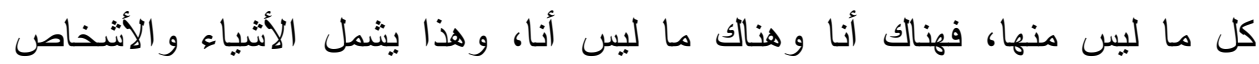
والأفكار أيضاً، وحدد بعض العلماء الآخر من خلال مزج كل كل تلأك الملامح فكان هناك (10) : (10)

-الآخر الحميم اللصيق(أنت)الحميمة و (ونحن)القريب، ويطلق على الو الدين بوصف

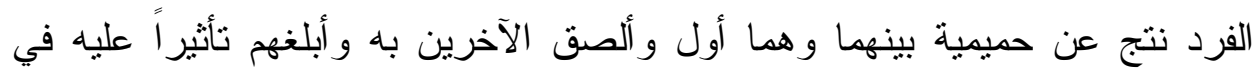

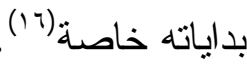
-الآخر القريب(نحن)باعتبار الفرد عضواً في جماعة أكبر ومن خلالها يكتشف ذاته

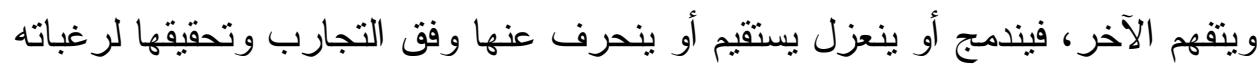
و إثباعها لحاجاته المختلفة، وهذه العلاقة بين الأنا والآخر الجمعي القريب هي وسيلة تحقيق الذات الجماعية لدى الفرد (Iv) .

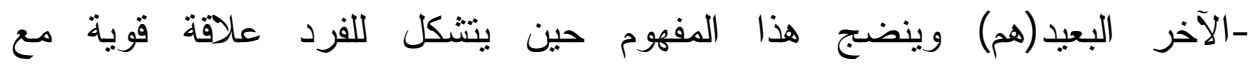
ال(نحن)القريب فيعتبر كل معادي لها بعيد، و الحدود بين الذات و (هم البعيد) نتاج

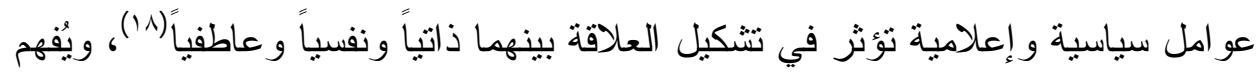

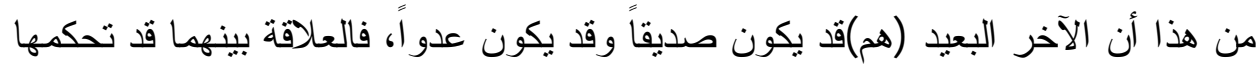
قيم أخلاقية ومعايير وقد لا تخضع لأي ضو ابط؛ ونعود بذلك إلى نقطتين مركزيتين في

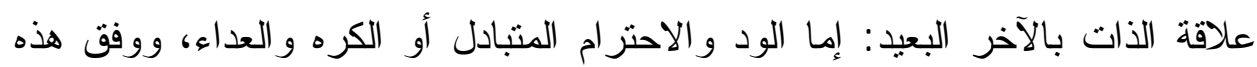

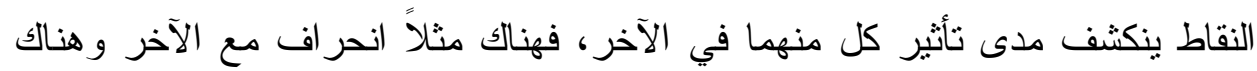

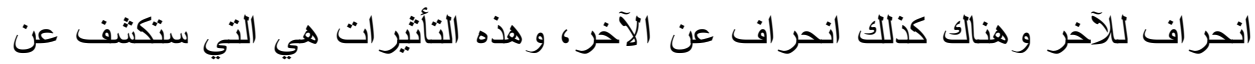


عدة تحولات للذات كنكر انها لهويتها وذوبان الشخصية أو انسلاخها وفقدانها للأمن و اغترابها وغير ذلك الكثير مما سيكثف عن بعض منه هذا البحث فيما يلي من لنه الصفحات . 


\section{من ملامح الذاتوصورة الآخر في نماذج من شعر (زاهي وهبي) دكتورة/ أمل عبل الله زين العابلين}

\section{القسم الثاني:التعريف بالثاعر (زاهي وهبي)}

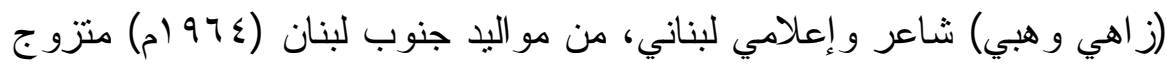

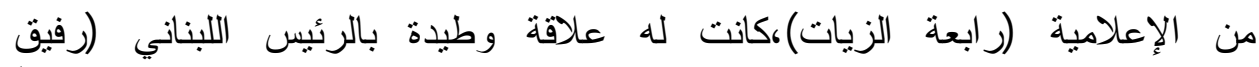

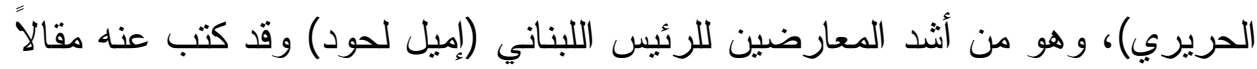

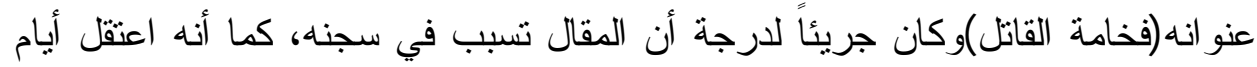

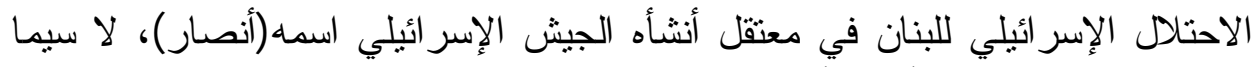

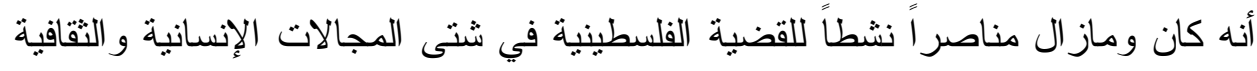
وغيرها؛ مما دعا لمنحه الجنسية الفلسطينية كثقدير لدوره التقافي والإعلامي في دعم القضية الفلسطينية وضحاياها.

ويبدو أن الثاعر (ز اهي وهبي)لم تشغله موهبته وشهرته عن همه السياسي وحسه

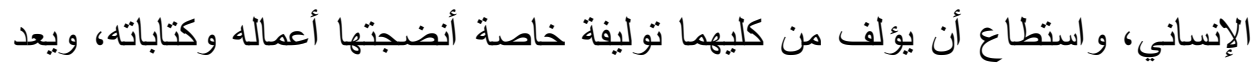

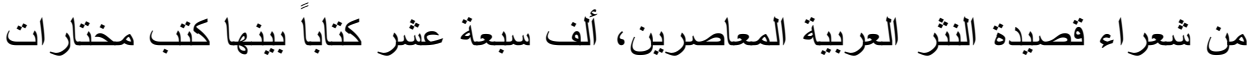

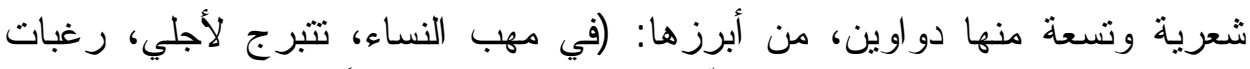

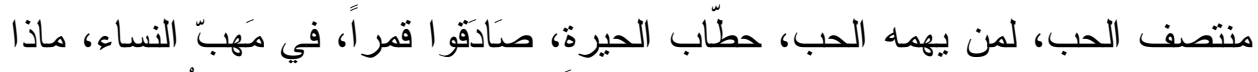

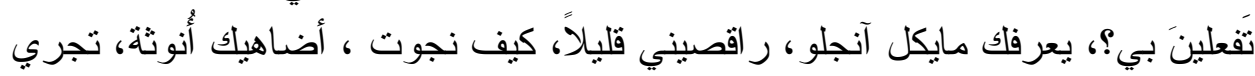
من تحتها الأنهار )؛ وتزخر معظم قصائده في هذه الدواوين بتجربة مغايرة حيث تمزي

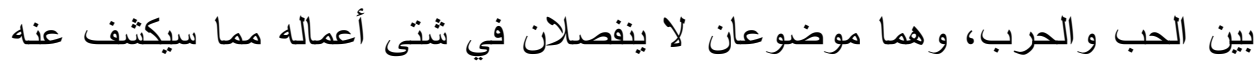

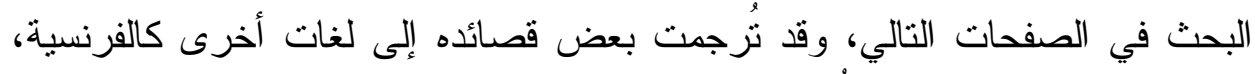
و الإنكليزية، و الإسبانية، وغُنيّت له بعض وفض ترجيت القصائد من قبل:(مارسيل خليفة، أحمد

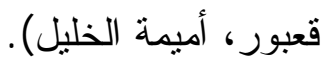

شارك (ز اهي وهبي)كذلك في إخراج عدد من المؤلفات النثرية منها الكتب و المقالات السياسية و الفكرية ومن أهمها: (ثلاث دقات، بيروت المدينة المستمرة، قهوة

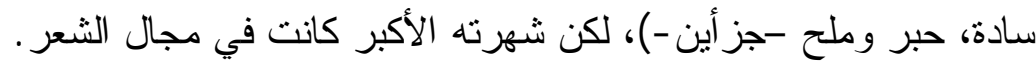

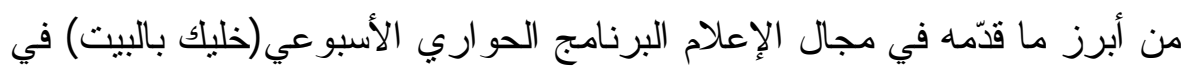

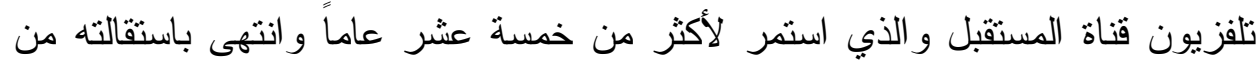

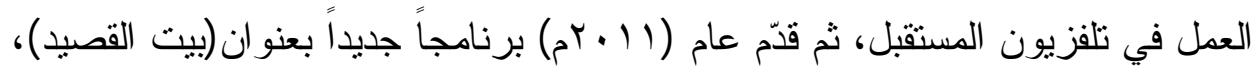

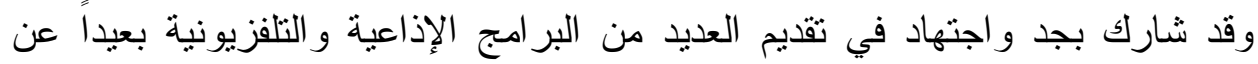

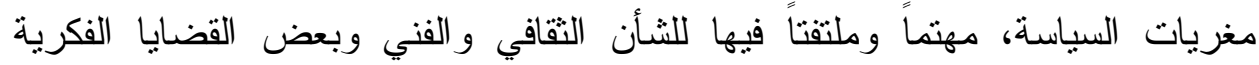

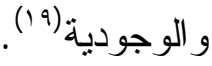




\section{المبحث الأول: حديث الذات وصورة الأنا}

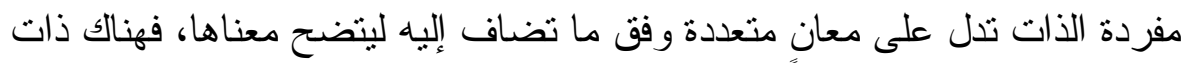

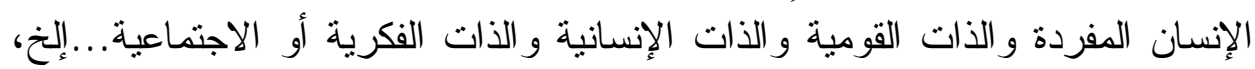

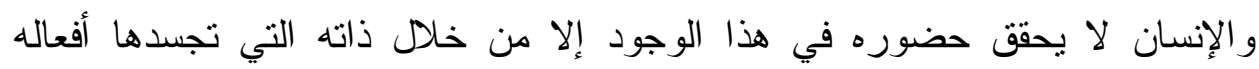

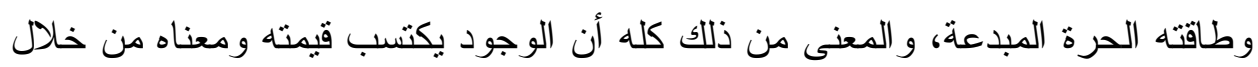

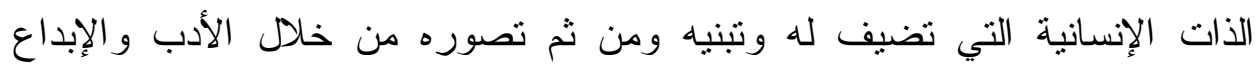

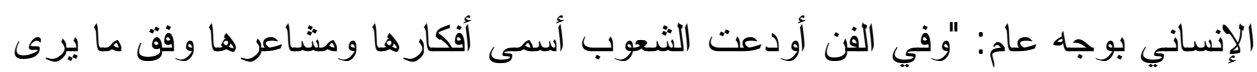

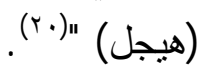

إن المبدع ليذوّب ذاته المفردة في عمله الإبداعي رغبة في إضافة الجمال للحياة

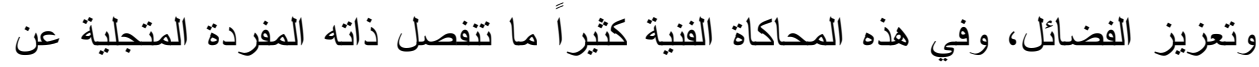

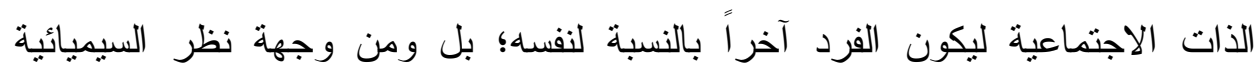

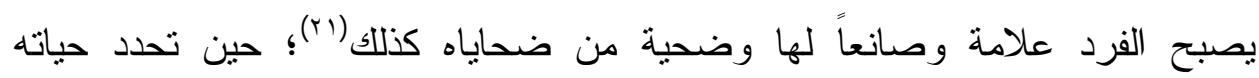
بأبعادها النفسية و المادية و الاجتماعية مساره في هذا العالم ؛ أي أن الفرد بإمكانه أن أن إناه

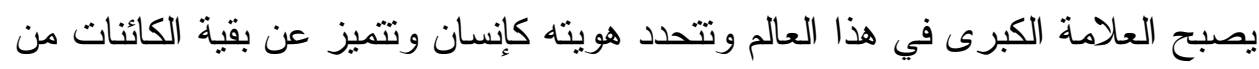

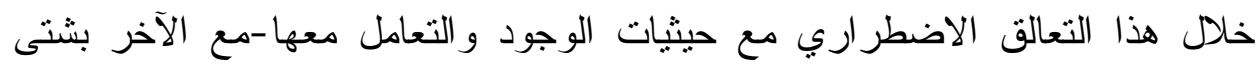
صوره وسيره في هذه المنظومة السيميائية. و الأنا ما هي إلى صورة من عدة صور للأذات الكبرى وقسم أساسي منها، وهي

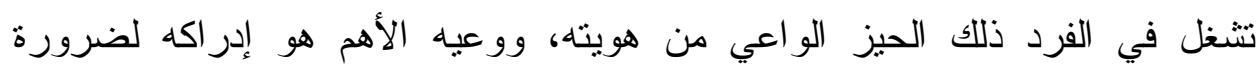

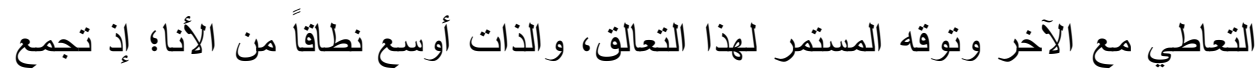

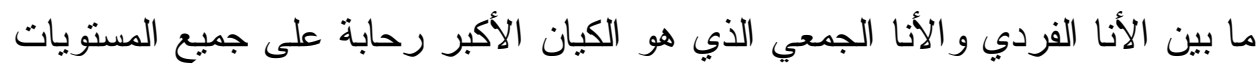

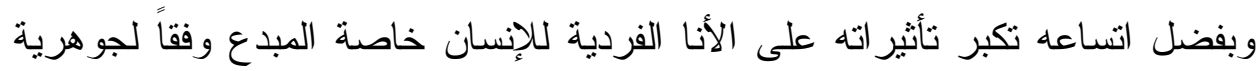
سيميائية ذاته في هذا الوجود .

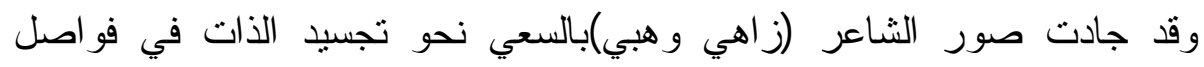

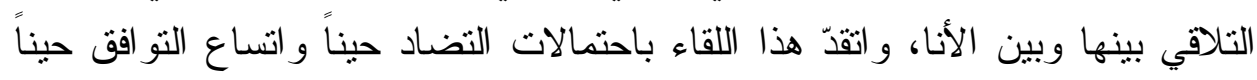
آخر ، بحيث بدت حيثيات التعامل بين الذات و الأنا باعتبار ها آخر أساساً لتتكيل مفاهيم

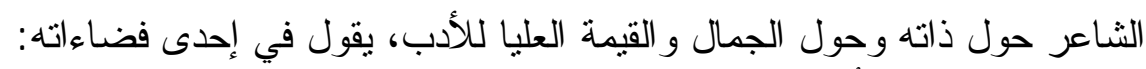

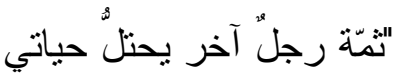




\section{من ملامح الذات وصورة الآخر في نماذج من شعر (زاهي وهبي) دكتورة/ أمل عبد الله زين العابدين}

$$
\text { رجلْ سِوَاي }
$$

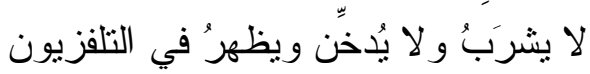

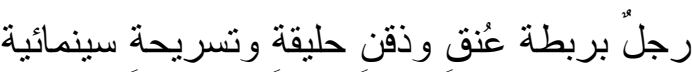

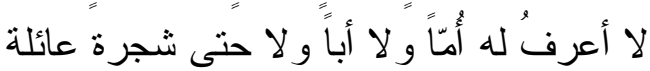

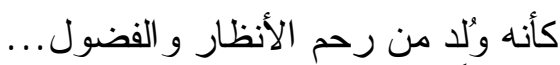

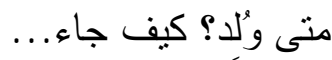

أسئلة فلا ألقى جو اباً

يبتسُُ بمكرٍ ودهاء

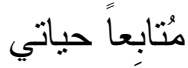

حياتي التي لم أعثْها كما ينبغي

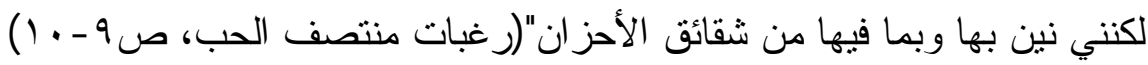

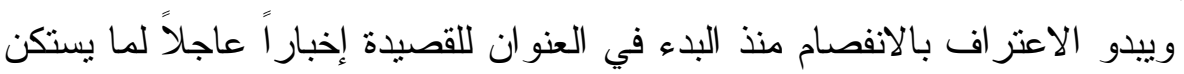

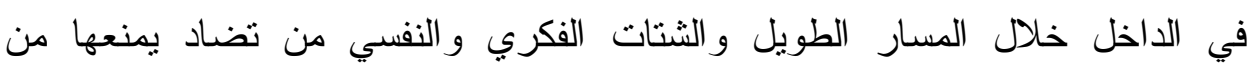
الوصول للذات المنسجمة.

وهذا الاففصام الذي يبدو متتاغماً مع و اقعية الصر اع و المعاناة يصبح شريحة

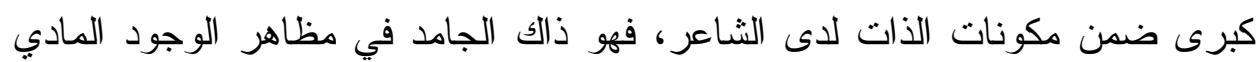

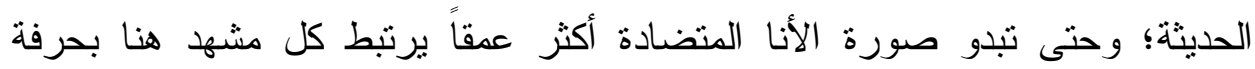

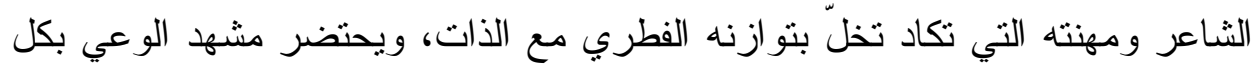
ذلك حين يخرج الثاعر من ذاته ليقف بمواجهة الأنا بعد قولبتها في مدار الآخر المتسلط: "أحقاً هذا أنا/هو ؟ أمنا: لكنه رجلْ سِوَاي

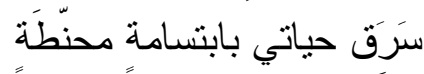
تسَلَّلَ فَي غَفْلة الأيَام

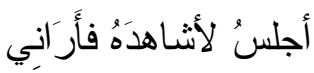

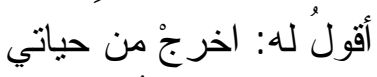

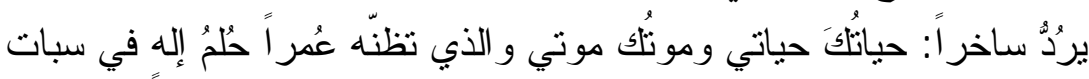


أقول : لماذا لا نُوقظه إذاً؟

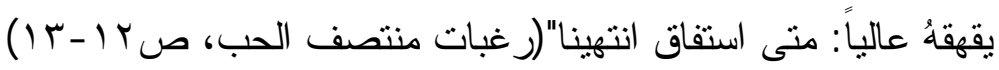
و السؤال يكبر ويكبر -هذا السؤال الذي يعد الخطيئة التي تعذب كل ذات ذات - ويبدأ

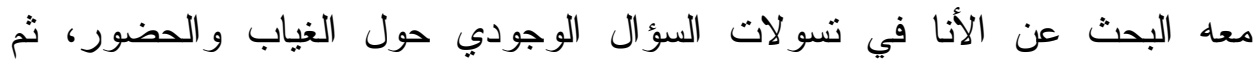

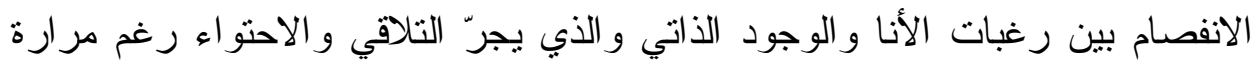

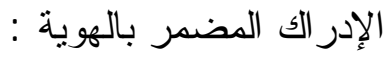

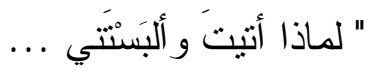
مَنْ أنت يَا هذا الضّاحكُ للنّاس؟

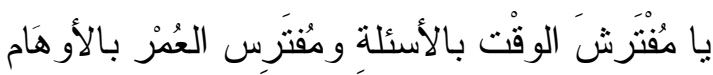

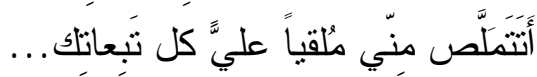
بلى

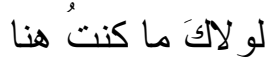

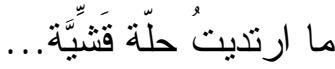

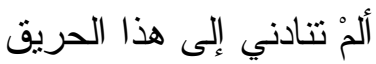

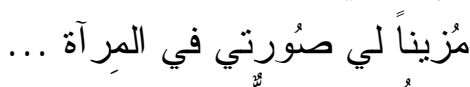
لست سوى ظلّ للكَ

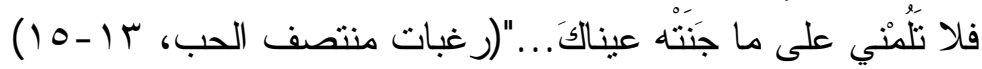
تكمن الإجابة الآن وتستكن كفريسة في المكاثفة وسياسة الثاعر هنا هي الخروج

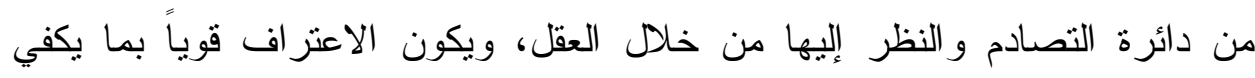

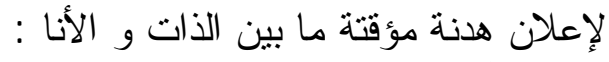

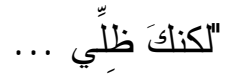

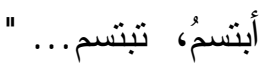

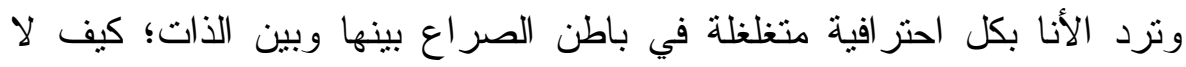

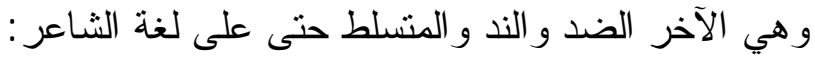

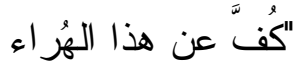

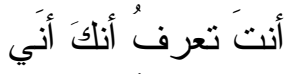
ما اختلست" منك سوى رغبة مكبوتة تحت جلد الحياة 


\section{من ملامح الذاتوصورة الآخر في نماذج من شعر (زاهي وهبي) دكتورة/ أمل عبد اللل زين العابلين}

قبلي وقبل غيري أحبيتَ مر ايا نفسكَ تلو مها حيناً وتتحني لها حيناً ... لو أنكَّ حقاً سو اي وتهاي

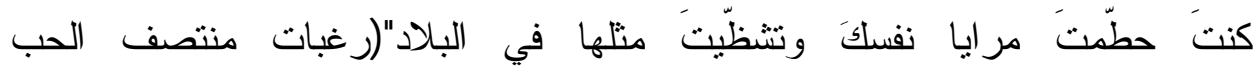
(19-119 (19)

وتجيب الذات بصوت يعلو مقرراً : "لا بيا ضدّي وندِي

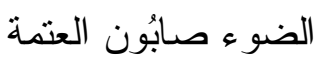
نصيبُ الحائر وقناعُ الحزين

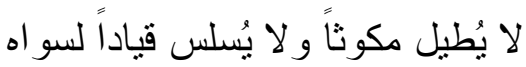

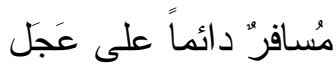

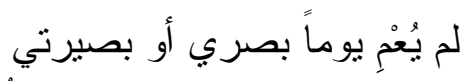

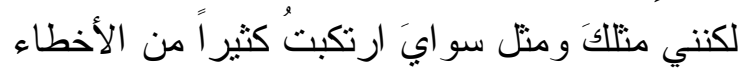

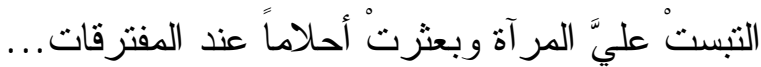
تو هَمت أنكَّ آخر، غافلاً أنكَ آخري

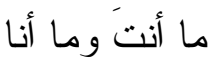
سوى وجهين لجُملة واحدة يكتبُها شاعر" هذه القصيدة"|(رغبات منتصف الحب . (r. - 19

إن اللقاء بين الذات والآخر جاء صورة للتضاد الكامل منعكساً في ضرورة السعي لتجسيد الهوية الحقيقية للثاعر، وهي صورة تنقلب في قصائد أخرى إلى التضاد الجزئي حيث يجيء حديث الذات محاسبة ومغامر ات في سبيل الوصول بل وتحديد المبادىء و التمسك بها في تللك المغامر ات المستمرة باستمر ار الحياة: "على دروب مرصوفة بحصى الثكّ" تزيدني أخطائي صو اباً.... أسئلتي مصابيح إنارة ظنوني مُفتر قات ... تجاوزتُ الأربعين ولم أنضـجْ بعدُ 


$$
\begin{aligned}
& \text { كل عام أزداد علامات استقهام } \\
& \text { الثيب ليس بياض حكمة }
\end{aligned}
$$

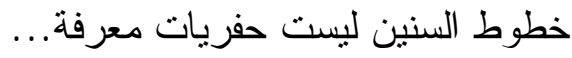

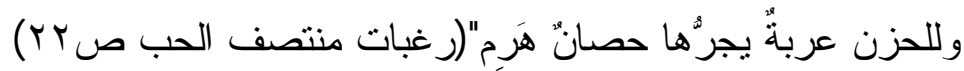

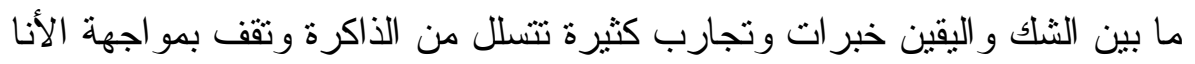
-الآخر المنسلط وتزكز انفعالات الثـاعر هنا وتعابيره على المباديء الفكرية و القناعات النفسية التي يختلف فيها كل منهما عن الآخر، الصراع نبض ونس مستمر

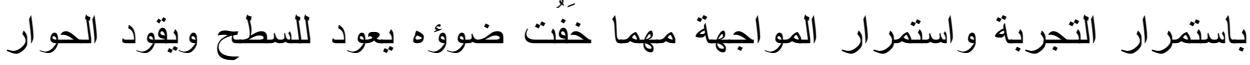
باتجاه الفصام من جديد : بان

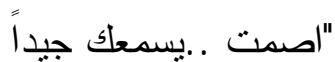

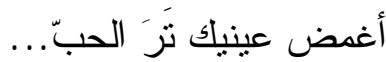

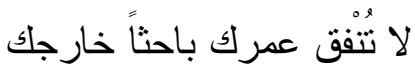
لا لذهب بعيداً

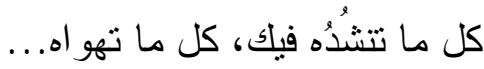

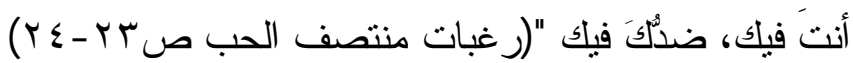
ثنائية(الانفصام والالتحام)في نفس الوقت لثلاثة جوانب من الثاعر :انفصال الذات عن الأنا الذكورية ثم التحام بالآخر الأنثوي في داخله:

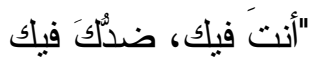

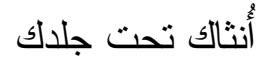
غرييك في المر آة اكسر الصورة، اكسر المر آة...

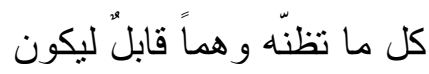

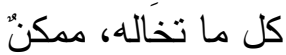

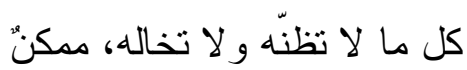

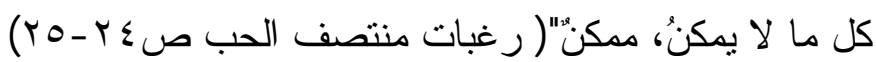
نعم هذا هو (ز اهي وهبي) وصل أخيراً و استقر في ذاته الذائبة في جانبه الأنثوي

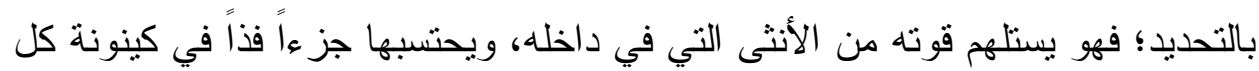


رجل -و العكس بالنسبة للمر أة ـ(rr)، هذه الثنائية الخاصة بالثاعر تصل به لتحقيق الأنا

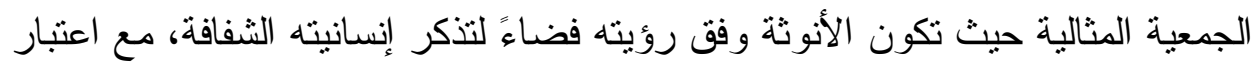
أن اللجوء إلبها آمن نماماً؛ بل جميل ومتمكن في انتصاره الأن على وفئ الأنا الفردية القاصرة في مقابل الخضوع لها ولمتطلباتها الضيقة الحدود وفق المنظور الإنساني.

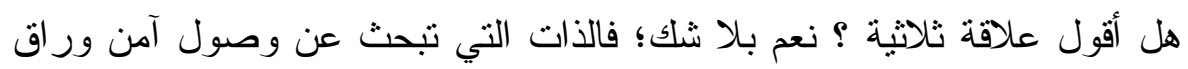

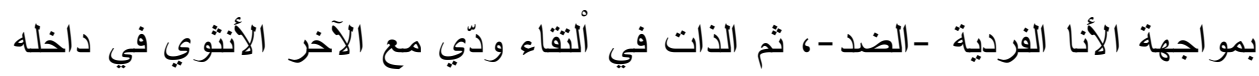

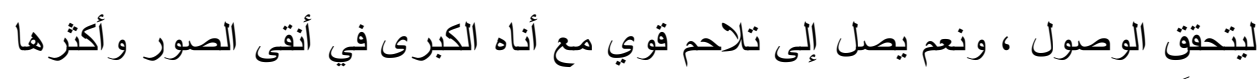

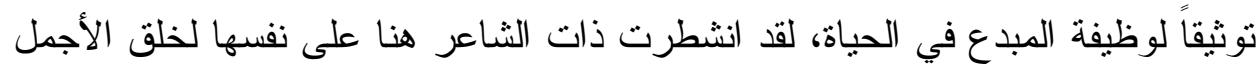
وتعزيز الفضيلة انشطرت ذاته المبدعة المتجلية عن ذاته الاجتماعية بوظيفتها المحدودة

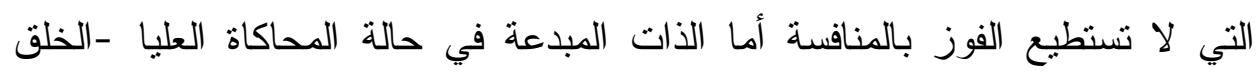

وفي بُعدٍ آخر بحثًا عن إثبات الوجود و التصدي للآخر مناورات أخرى بين الذات

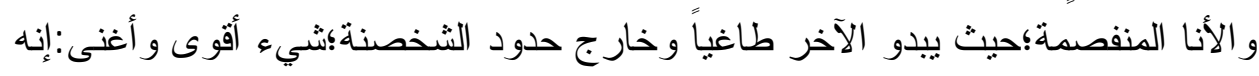

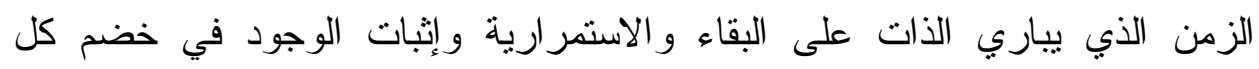

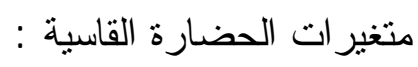

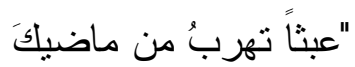
تبني للكَّ بيتاً تعلَّق صور تلكَ الجديدة على الحائط.

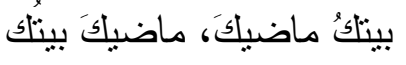

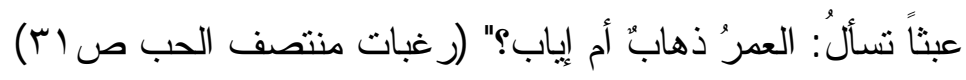

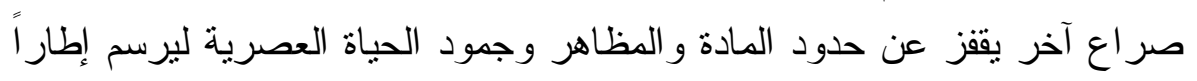
خارجياً له سطوته وهيمنته في تشكيل قرار ات وصور التهن الثاعر ورؤيته الكونية:

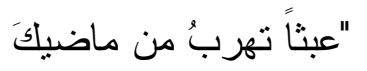

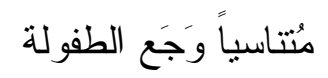

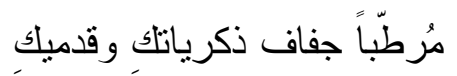

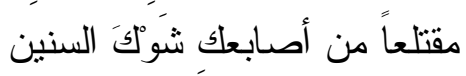
أجملُ ما فيكَ الترابَ الذي فيكَّ ... 


$$
\begin{aligned}
& \text { عُدْ خفيفاً أئهُها الفتى }
\end{aligned}
$$

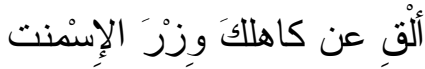

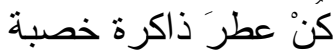

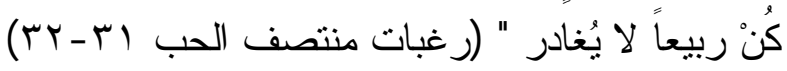

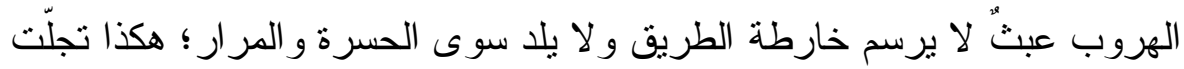

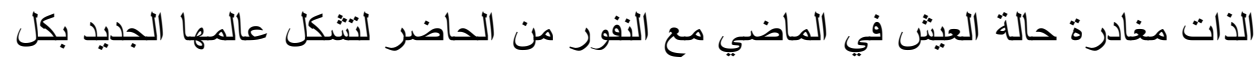

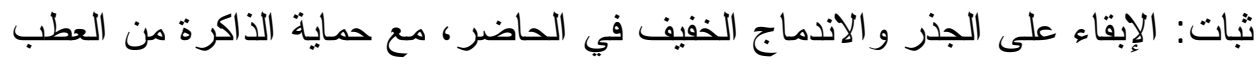

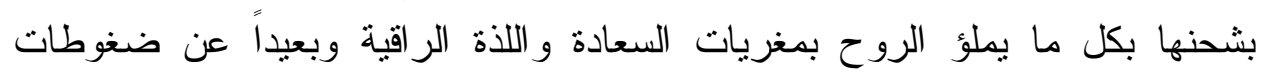
الحاضر المادي و عنفه: "كُنْ عشبةً بريئة أو سحابةً حائرة وعنة

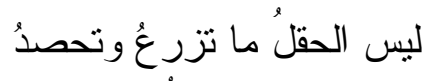

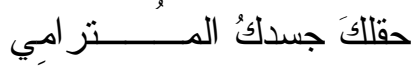
بين طُفولتيَنْ :

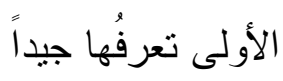

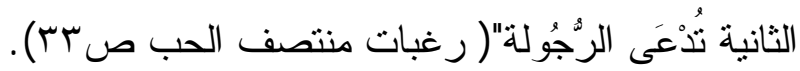
المبحث الثاني: المرايا وحديث الآخر

ينز امن صنع أول مرآة مع ظهور أسطورة (نرسيس) وقد يدعو هذا التزامن

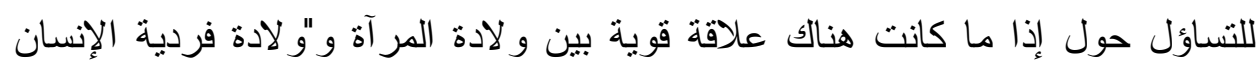

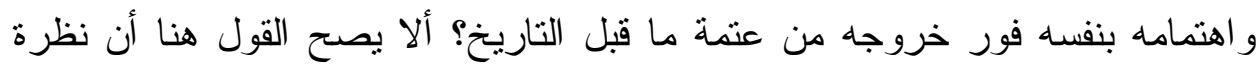

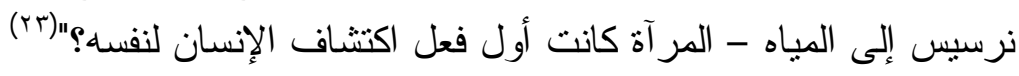

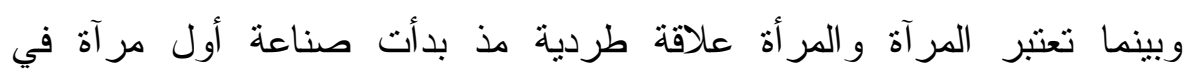

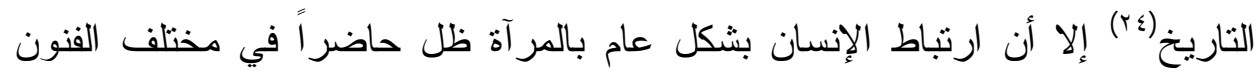

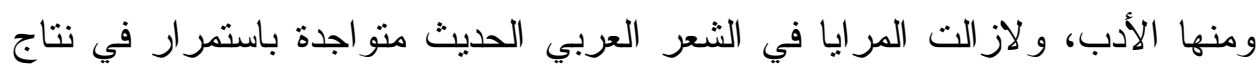

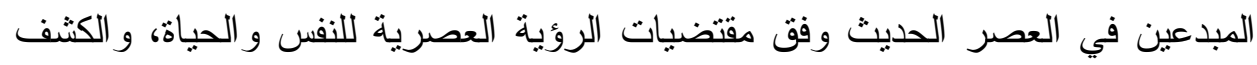
عن زواياها في النص الأدبي وخبايا وجودها وظلالها على النص بل ومقتضيات هذا

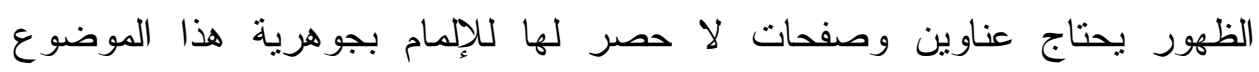

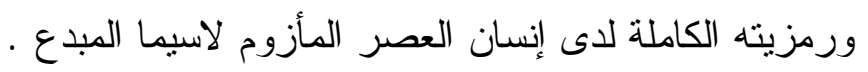




\section{من ملامح الذات وصورة الآخر في نماذج من شعر (زاهي وهبي) دكتورة/ أمل عبل الله زين العابلين}

وفي جولة مركزة حول رمزية المر آة في الثعر الحديث نجد أن عدة در اسات فنية حديثة ارتكزت على تاريخ المرآة ووجودها الفلسفي الصوفي و والأسطوري و الثعبي (ro)، ولكثرة توظيفها الفني أصبحت إحدى آليات شعر الحداثة، ولها حضور معرفي شعري فيه مكاشفة للذات تقود حركة الأمل أو الكثف أو الرؤيا في ثنائية

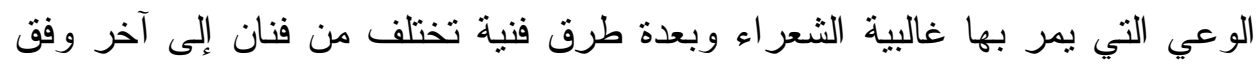
تقافته وتوجهه الفكري و الديني و الاجتماعي.

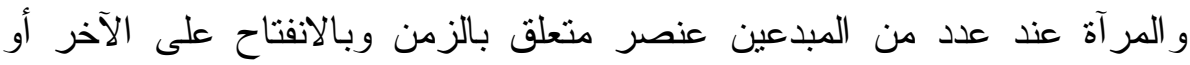

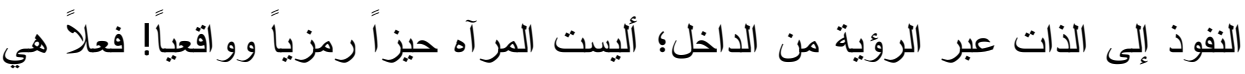

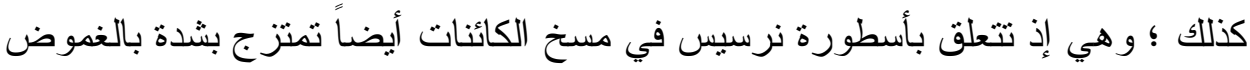

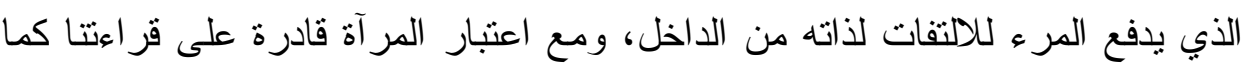

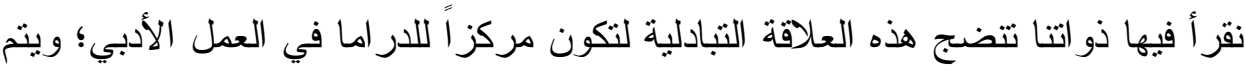

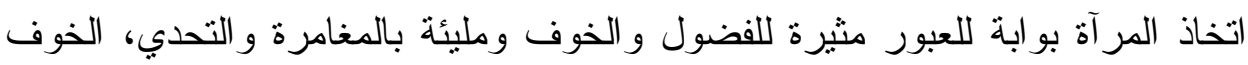

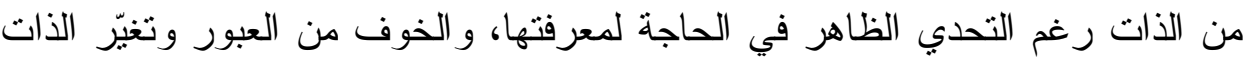

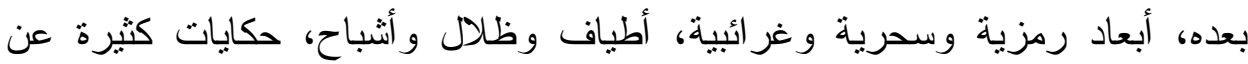

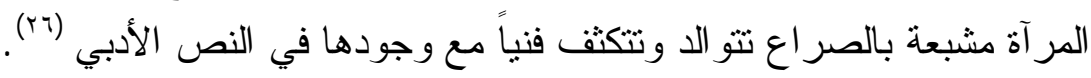

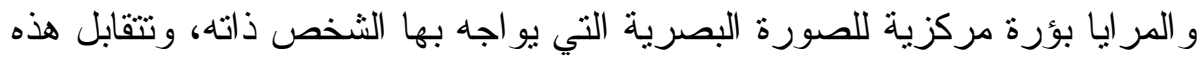
الوظيفة الفيزيائية مع وظيفتها الفنية الرمزية في كون المر آة وفق كل منهما هي الحيه الحيز

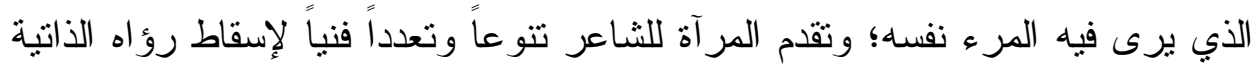

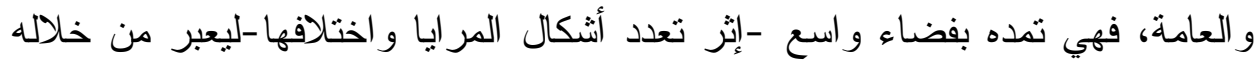

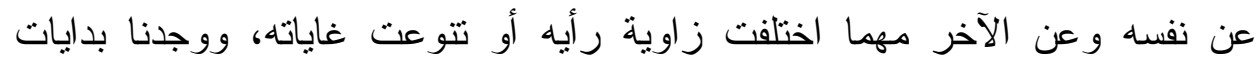

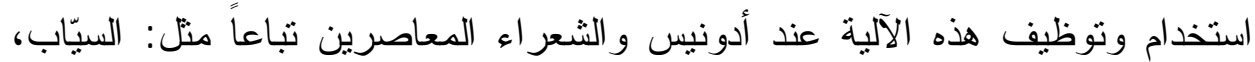

ونازلك الملائكة عفيفي مطر ، البيّاتي، صلاح عبد الصبور وغيرهن هم الكثير (rV)

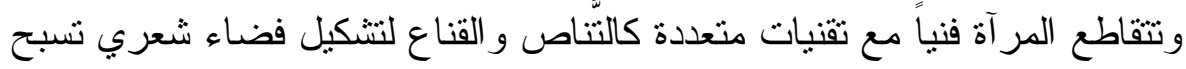

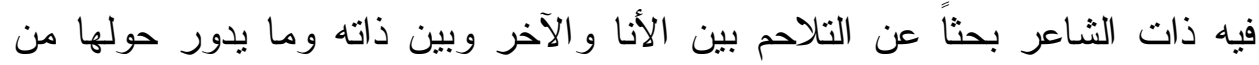

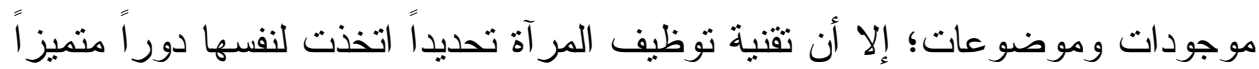

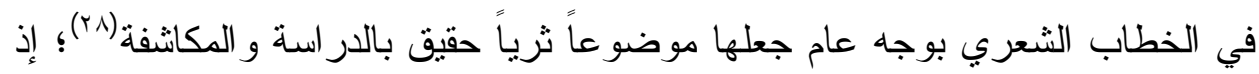

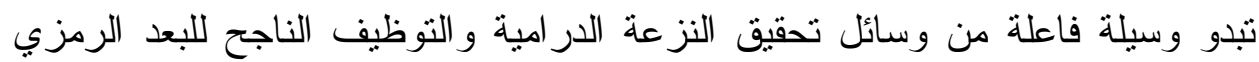


والأسطوري بما في كل منهما من عمق يساهم في دعم معمارية النص الثعري الحديث.

ومن خلال قراءة شعر (زاهي وهبي)وجدت للمرآة حضوراً متعدد الوظائف

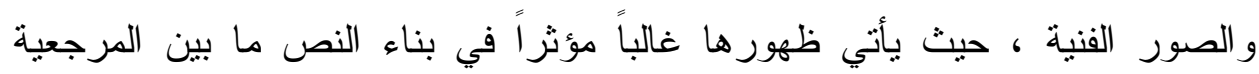

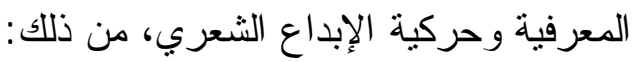
- البحث عن الذات، و استخدام المر آة قناعاً لها تعبر به الذات الذات عن انفصالها عن صورة

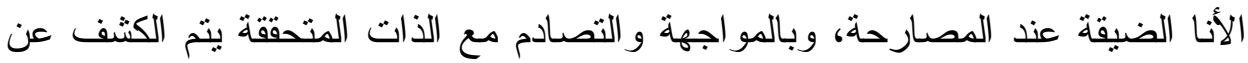

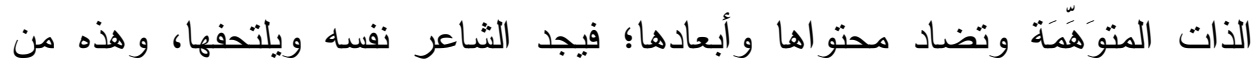
الصور العميقة المتكررة في شعر (زاهي وهبي) المعبرة عن حضوره الإنساني

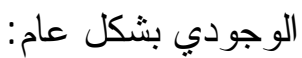

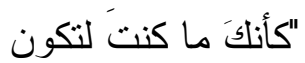

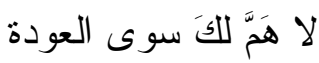

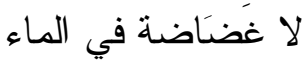

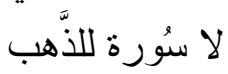

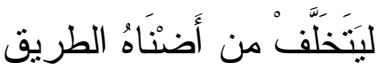

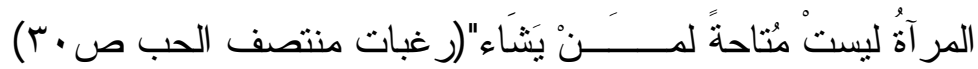

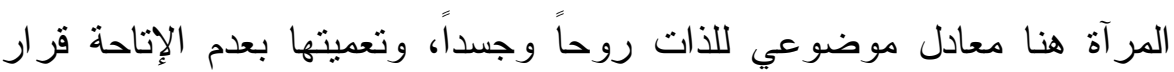
بعزلها عن الأنا التي تتمرد باستمر ار وتتصادم موفر معها.

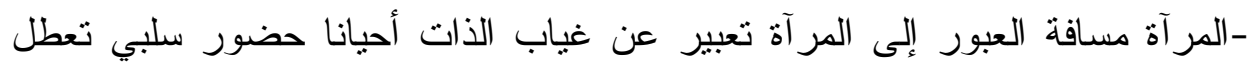

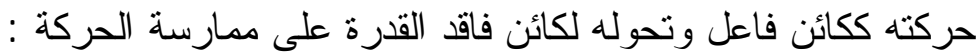
"غريبُكَ في المر آة

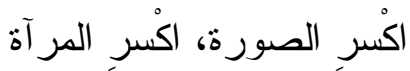

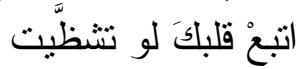
تتاثرْ في أرجائكَ فئَ

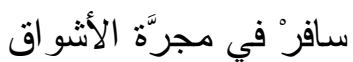

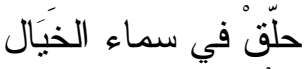

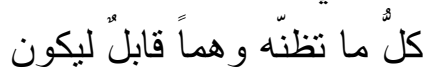




\section{من ملامج الذاتوصورة الآخر في نماذج من شعر (زاهي وهبي) دكتورة/ أمل عبد اللل زين العابلين}

كلّ ما تَخالهُ، ممكنٌ

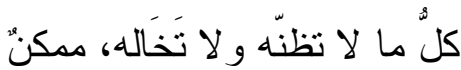

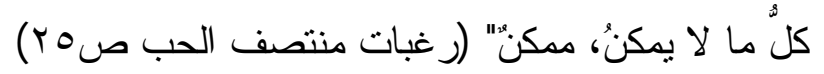

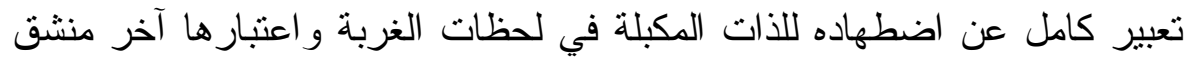

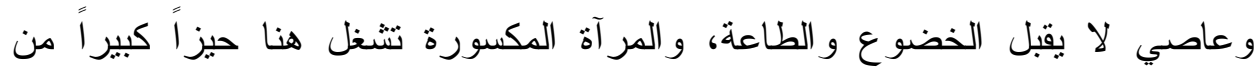

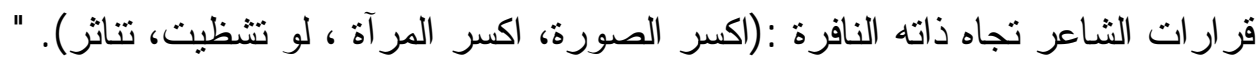
إن المر آة المكسورة المترددة لاى الثاعر ما هي إلا رمز يشير بعمق للهوية المنفصمة في لحظات الكثف و البحث عن الذات؛ بدلالة ما توحيها اللحظات التأملية في المر آة:

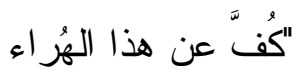

$$
\begin{aligned}
& \text { أنت تعرف 'ُ أنلكَ أنّي }
\end{aligned}
$$

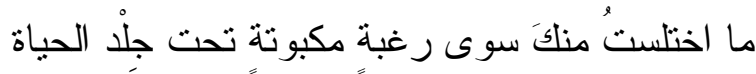

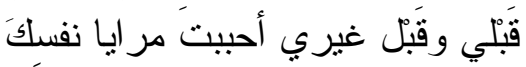

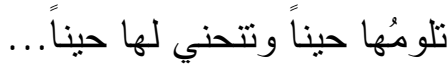

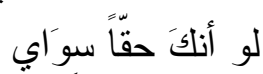

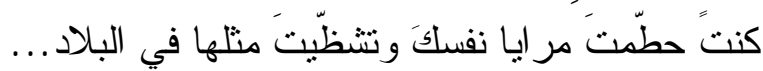

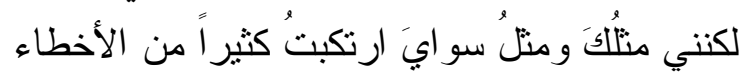

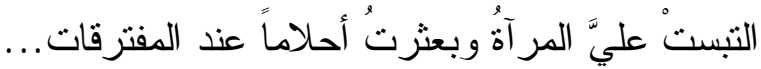

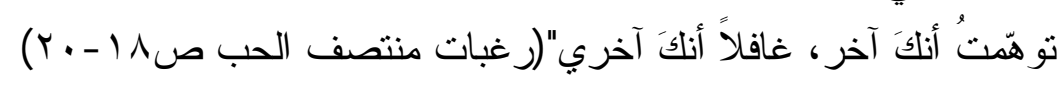

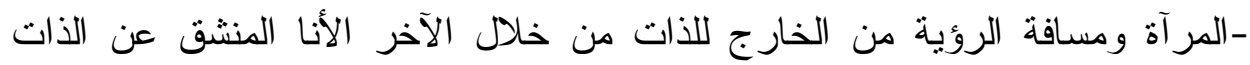

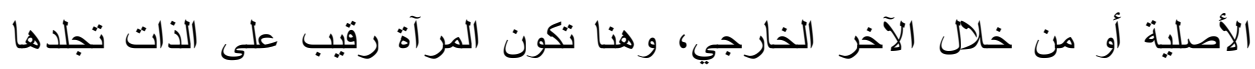

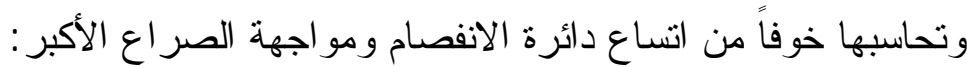

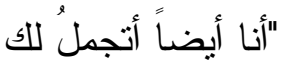

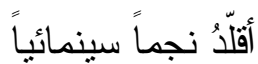
على وجهي ابتسامةٌ عصية

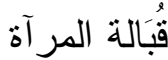

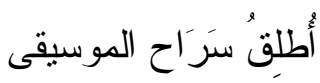




$$
\begin{aligned}
& \text { أُغنِي على لَيَلاي كذئبِ لا يُضْنِيه التربُص }
\end{aligned}
$$

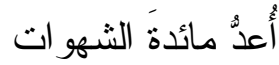

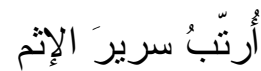
المر آة تتجسد في هيئة ضمير إنساني ونتخذ بعداً جديداً في الحيز المكاني و النفسي

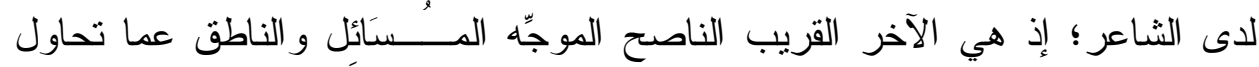
الذات التستر عليه. -المر آة للتجلي: لها القدرة على كثف الذات و الآخر على حد سواء سواء كان ذات منشقة أو آخر أو عالم بأكمله -إما في حالة التصالح و التبادل النافع حيث لا لأل مسافة بين

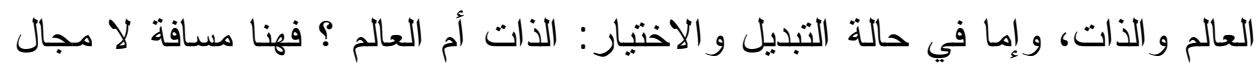

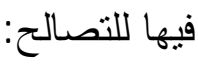

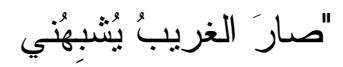
صارَ الغريبُ مر آة

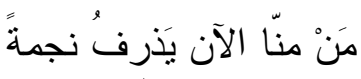
مَنْ منّا الآن يُنتِّي

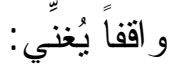
"حبييتي و أنا بنت وصبي على خدّّها قُبلة يدُها في يدِي مثل كفِّها أحلامُنا صغيرة أن تصيرَ لنا خز انةٌ نعلقِ فيها ثيابَنا 


\section{من ملامح الذات وصورة الآخر في نماذج من شعر (زاهي وهبي) دكتورة/ أمل عبد الله زين العابلين}

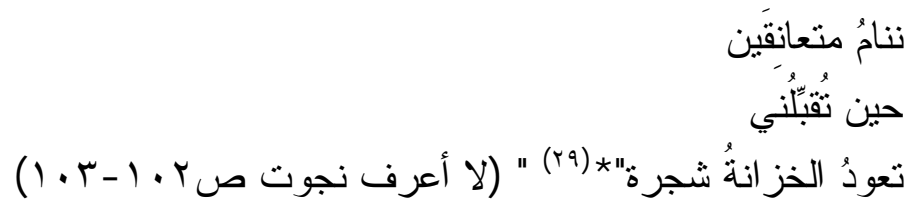

وقو تكون المرآة محور الرؤية؛ الصورة الواقعية المادية للمجسدات و المجردات

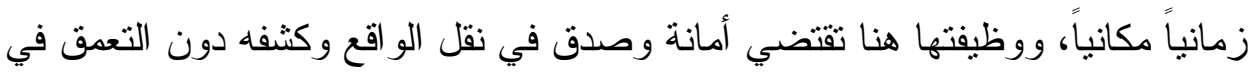

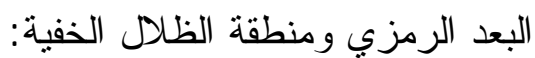

"في الليلة الأخيرة تنتعش ذاكرتي كمر آة

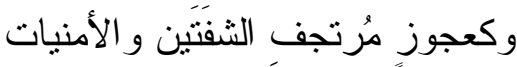

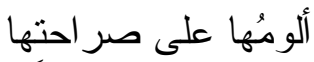

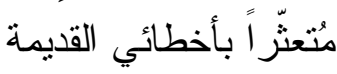

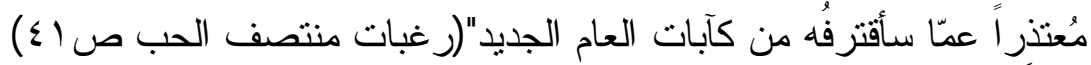

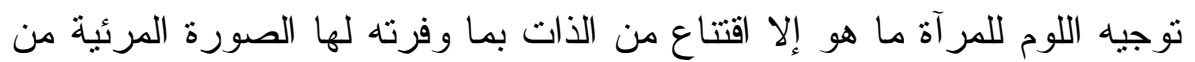

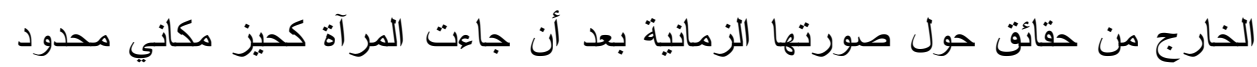
يتسع باتساع الزمن؛ وتفقت الذاكرة التي هي مقابل موضوعي للمر آة ليأتي التعثر كصورة مقابلة للمر آة الثفافة لانكسار ات الماضي، ثم يأتي الاعتذار كصورة مقابلة للمر آة المتعرجة المبهمة الكئية عند استثر اف المستقبل. -المر آة وسيلة الانتقال إلى الذات والتحول من حضور الذات القيمي والخلقي خاصة إلى الحضور الشعري، و المر آة أداة للتأمل والتفكر عبر الخلق الخيالي، وبدون شك التك فالحضور المر آوي هنا من مكونات التجربة الشعرية :

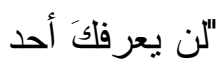

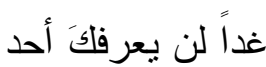

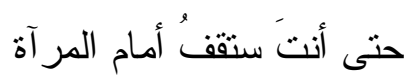
تحدِّق طويلاً

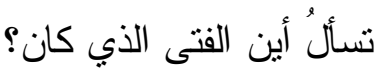

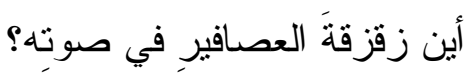

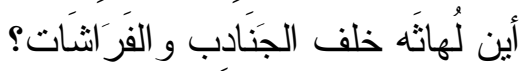


أحقاً أنتَ هو الآنَ كَان

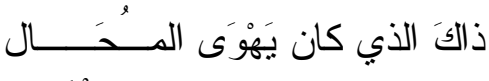

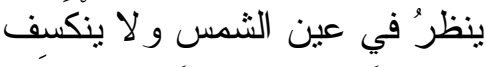

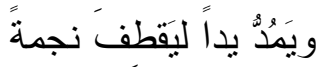

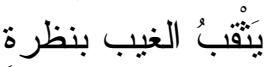

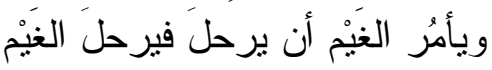

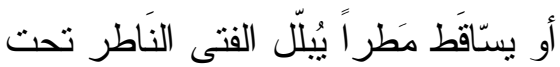

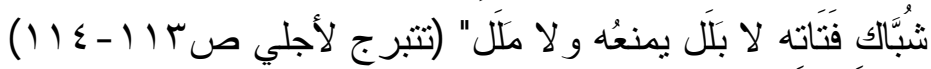

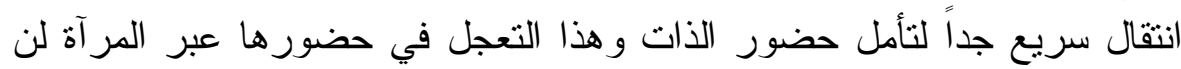
يخلف سوى الخوف و التردد أمام تجليات كثثرة تتربع على عرش الذات في لجج

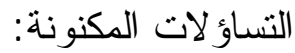

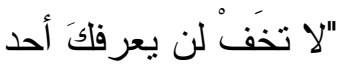
حتى أولئكَ الذين صَفَّقُ اللكَ طويلاً

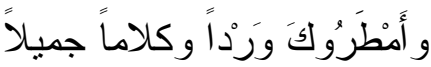

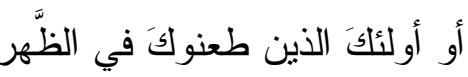
وبَاعُوْكَ بين صَكَاتَنَنْ

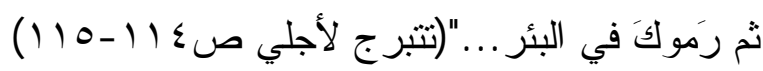

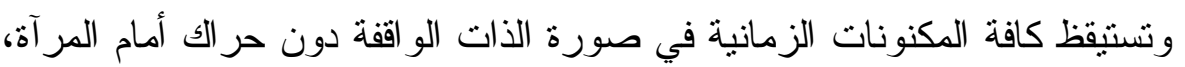
تصلب يكثف عن الثبات أمام الرؤية الواضحة لموقع الذات وتنكوينها من خلال

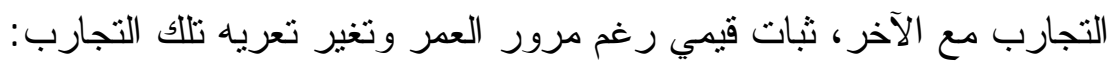

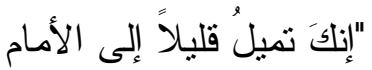

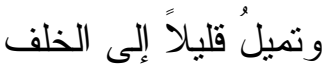
وتخلط قليلاً بين اليوم و الأمس الخس الخس وتنادي بأعلى صوتلكَ

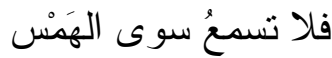

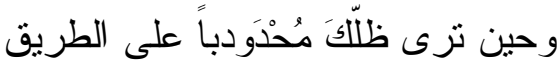

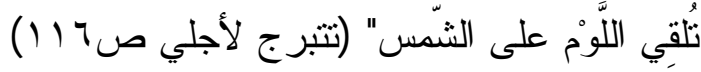


بعد مسافة متر امية الحقول الدلالية للمر آة تدخل الذات إلى حيز الظلال، لتكون لها

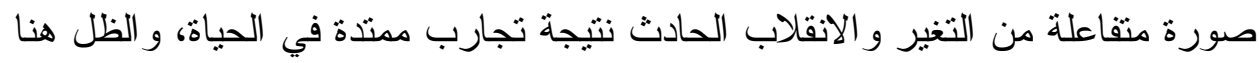
تعرية للآخر الكامن و المختبيء في داخله الذي سيبرر الماضي بجميع تفاصيله بلوم

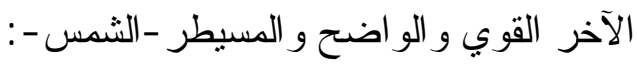

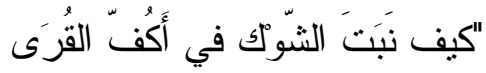

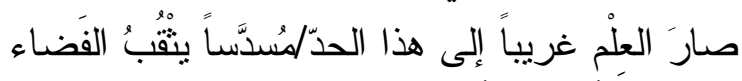

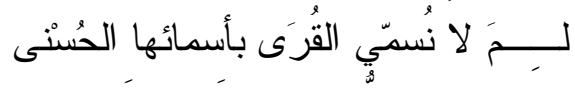

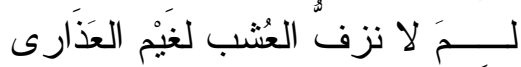
وَجْهُ مَنْ في البطاقة الزَرْقَاء

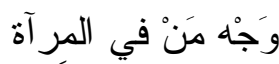

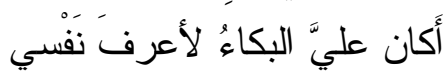

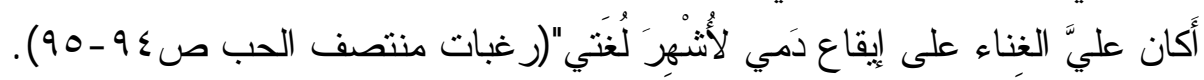

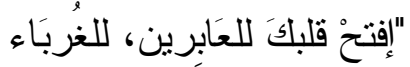
كُنْ شُرْفة، حديقة

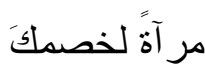
لا تكنْ سجناً أو جدارًا لا تكنْ عاصفةً حمقاء

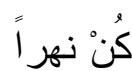
كُنْ جسر اً لمــــنَّاة الريح

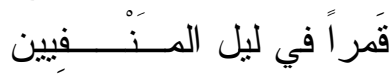

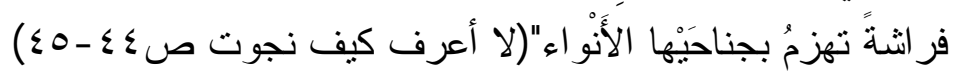
إن رمزية المرآة لدى الثاعر تحيل للحيرة المعرفية بين طرفي ثنائية الوعي:

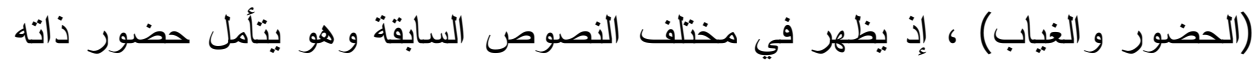

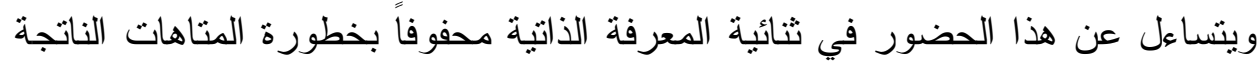
عن هذا التأمل و التساؤل المستمر . 


\section{المبحث الثالث: الأت و المــرأة}

تبدو المرأة عند(زاهي وهبي) البعد الآخر للذات ومكمن القوة فيها؛ خاصة حين

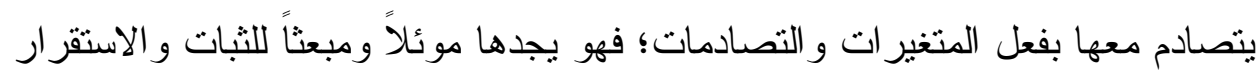

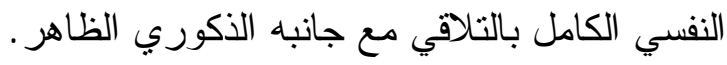

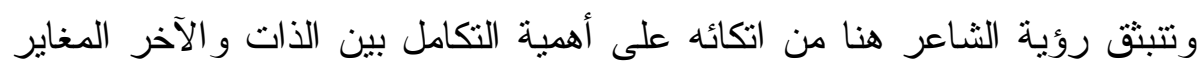
و الامتز اج الجذري به ليطلق لنفسه العنان في التعبير عن وجودها ونها وفاعلية هذا الوجود

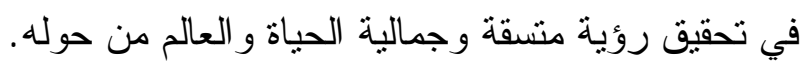

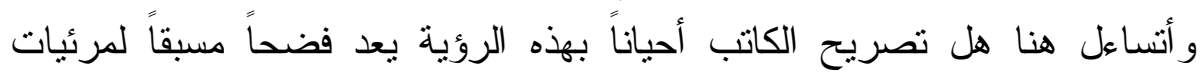

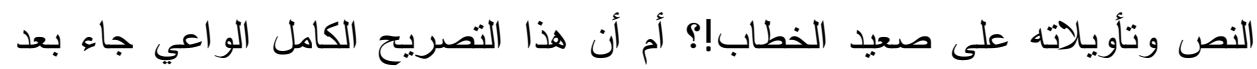
تعرية للذات من خلال الممارسة المستمرة لتوجيه الخطاب الثعري وتوظيفه نحو لإنه

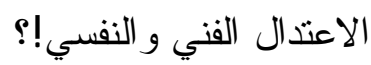
و عند معانقة بعض نماذج تلك الرؤية عند الثاعر نجد المرأة تظهر بصورة المعادل الموضوعي شبه الدائم لاى الثاعر؛ في وتيرة متصاعدة مترددة ما بين جانبين:

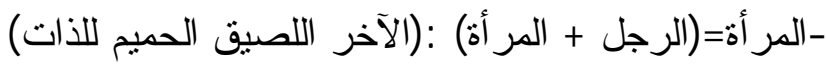
-المر أه= (الرجل = المر أة): (الآخر الخارجي المؤثر في الذات)

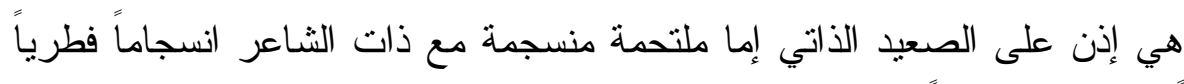

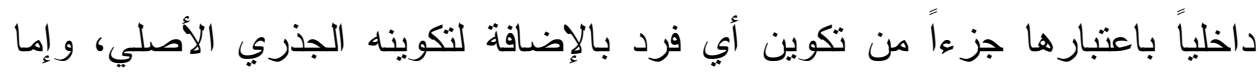

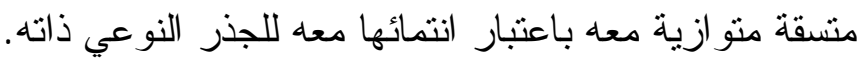

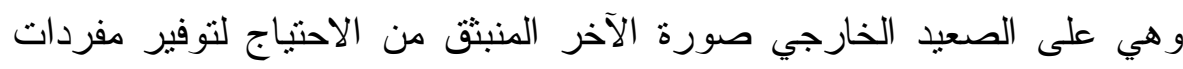

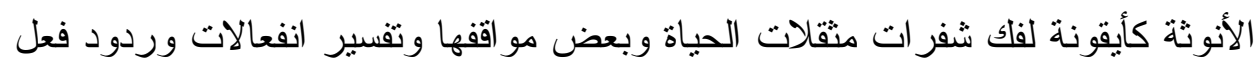

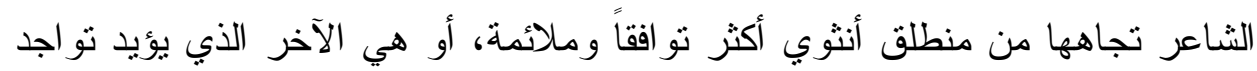

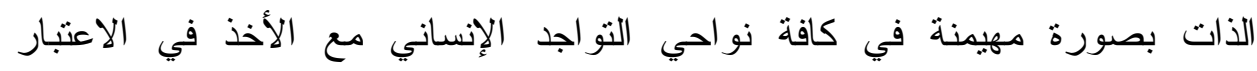

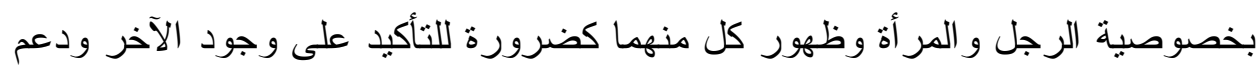
خصوصيته . 


\section{من ملامج الذات وصورة الآخر في نماذج من شعر (زاهي وهبي) دكتورة/ أمل عبل الله زين العابلين}

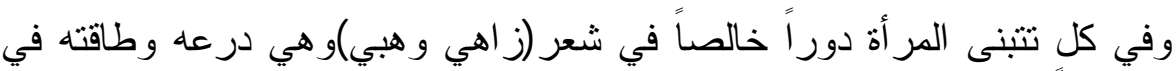

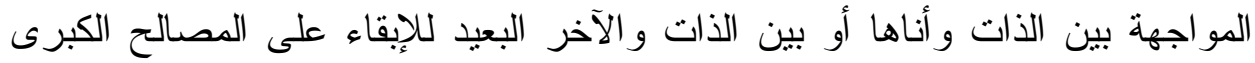

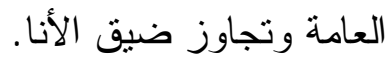

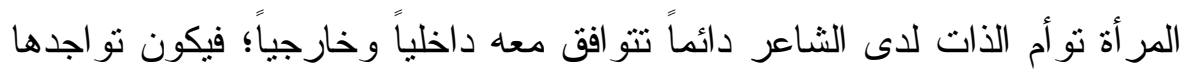

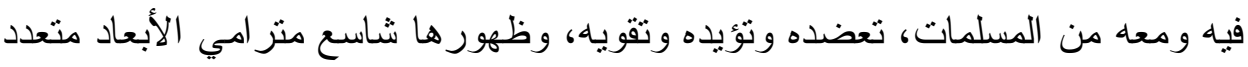

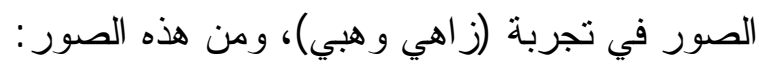

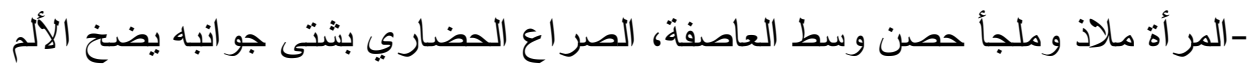
في ذات الثاعر فتجيء المر أة هدنة بين الذات و الآخر الفردي و الجمعي البعيد:

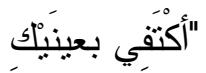

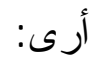

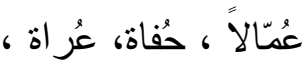

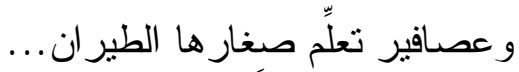
فقط أنامُ على يديك و وأحُُ

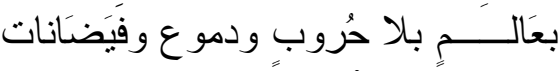

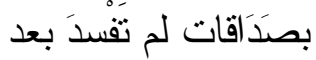

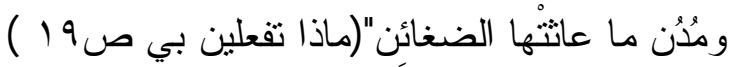

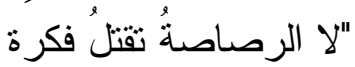

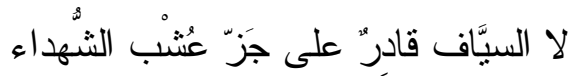

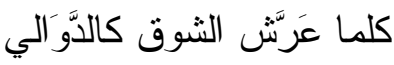

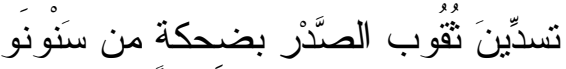

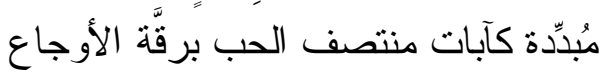

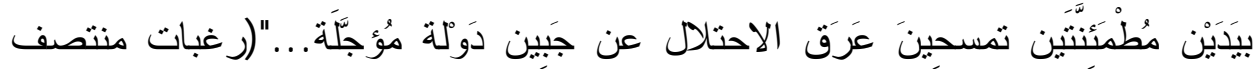

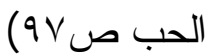

هبت رياح التصادم تدمر نظرة الثاعر للعالم وتتنامى أحلامه بالسلام، إنه يبحث الئ

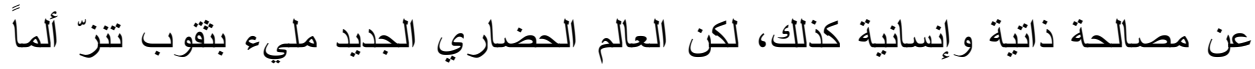

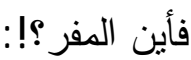
"أحتضنُكَ و لا أفتحُ النافذة، 


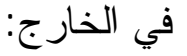

$$
\begin{aligned}
& \text { شمس صدئَة }
\end{aligned}
$$

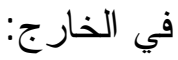

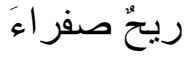

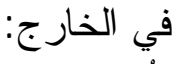

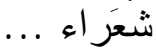

$$
\begin{aligned}
& \text { جَسَدَي نَاحل } \\
& \text { وصوتي جفّ من فِرْط النساء } \\
& \text { لكني، أقون لها: } \\
& \text { أنتِ رجائي في العاصفة }
\end{aligned}
$$

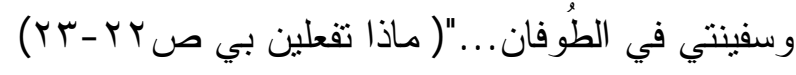

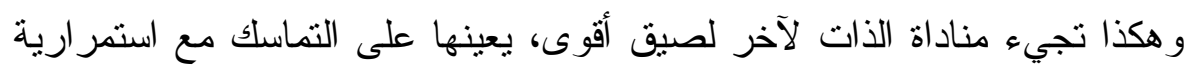

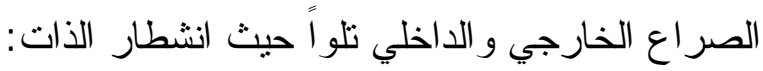

$$
\text { ، تعالي" }
$$

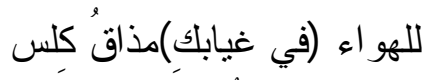

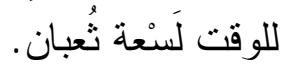

تعالي، نجة الصبح كثَرَتْ عن أنيابها

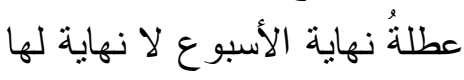

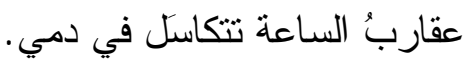

$$
\begin{aligned}
& \text { ، تعالي } \\
& \text { ولا تفتحي النافذة... } \\
& \text { ، تعالي ولان } \\
& \text { وشتّي قَميصي أنَّى شُّتِ }
\end{aligned}
$$

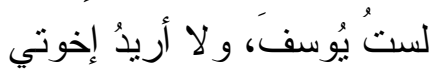

$$
\begin{aligned}
& \text { تباً لهم . } \\
& \text { دَعِيهم يكبرون في الخديعة }
\end{aligned}
$$




\section{من ملامح الذاتوصورة الآخر في نماذج من شعر (زاهي وهبي) دكتورة/ أمل عبد الله زين العابلين}

ودعينا نتقافزْ كغزَ'الَين شَاردَين

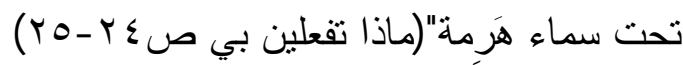
-الآخر البعيد والذات المنتكلة في صورة المرأة، حيث يبرز الثناعر جانين هانبه الأنثوي القوي للمو اجهة مع الآخر البعيد وهزيمته لاستشعار الر احة و المصالحة الكبيرة:

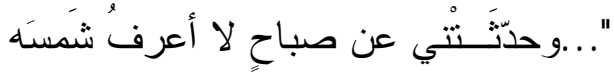
عن وطن لا أُدركُ كَنَهِ

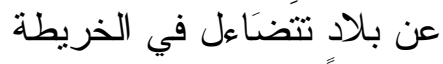

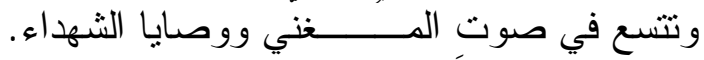

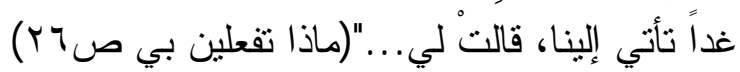
انفصال عن الآخر القريب الجمعي وهو الوطن بسبب انفصال أكبر عن الآخر

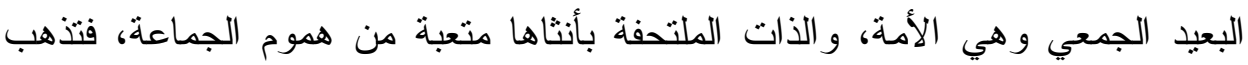

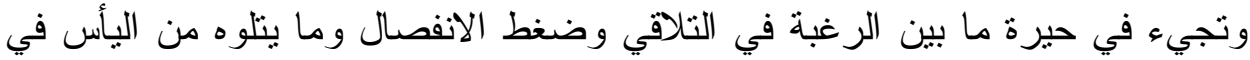

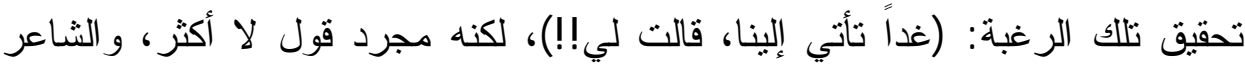

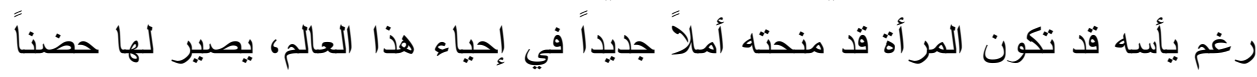

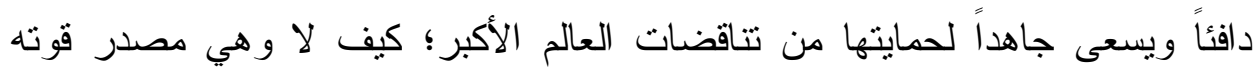
ونضاله وما بقي له بعد ضياع الوطن:

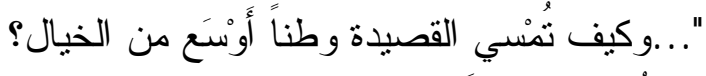
هنا أُعمرّ للك بيتاً لا تقوى الدَّبابة على هَدْمهه و لا يدخله الغُزَاة هنا قلبي

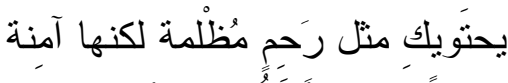

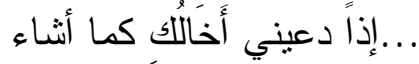
نجمة مُشتِّة في وَسَّاوِسي

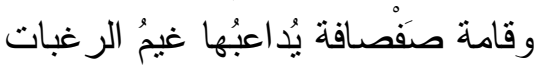

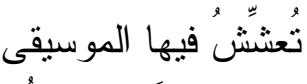

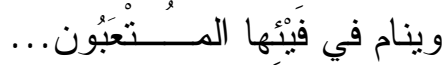
كيف آتيك و الجند عند باب دارك؟ 


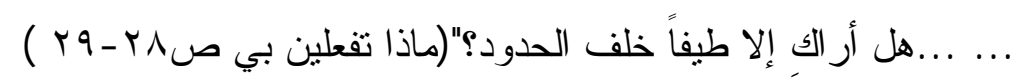

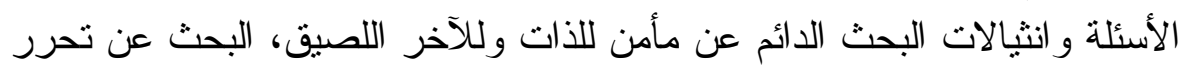
كامل لهما من هيمنة الآخر البعيد العدو المدمر، المرأة في هذه القصيدة رمز لفلسطين

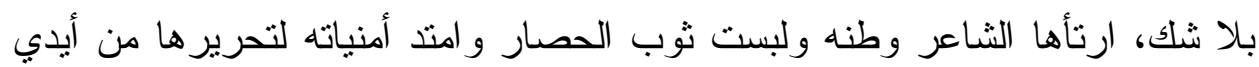

$$
\begin{aligned}
& \text { الآخر العدو الغانش: }
\end{aligned}
$$

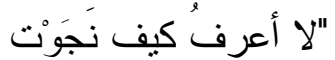

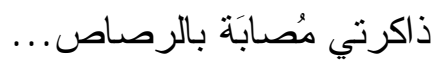

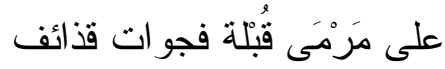

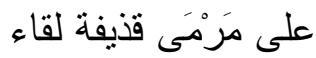

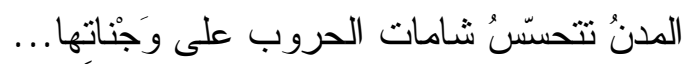

$$
\begin{aligned}
& \text { وَجْهُكَ تَمَيمَة } \\
& \text { وَجْهُك بلاد }
\end{aligned}
$$

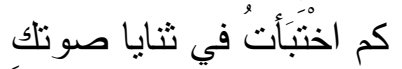

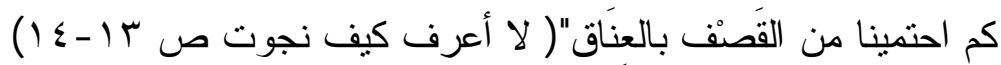

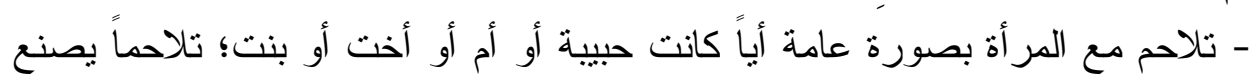

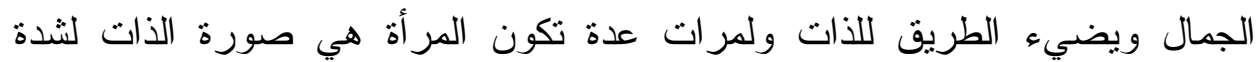
التحامها وتقف بقوة في وجه الآخر البعيد الجمعي: "ماذا أفعلُ بكفِّي

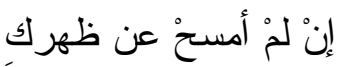

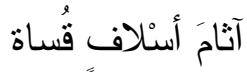

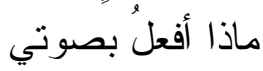

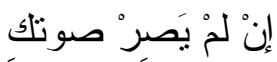

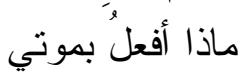

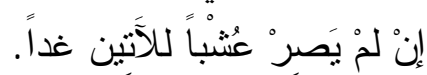

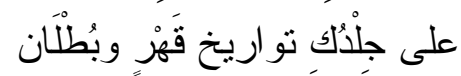

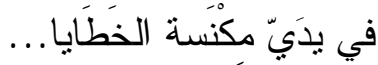
في صدركِ برْق الحريّة/عَصْف الأحرار 


\section{من ملامح الذات وصورة الآخر في نماذج من شعر (زاهي وهبي) دكتورة/ أمل عبد الله زين العابدين}

$$
\begin{aligned}
& \text { يمحُو نَكَك و أكتبنَك }
\end{aligned}
$$

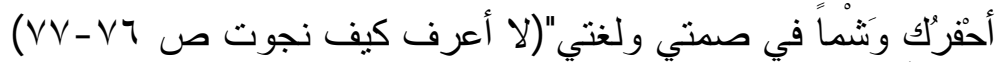

صورة منزامية عبر الزمن الثعري مستلهمة حبكتها الدرامية من المرور على على الهي الحكايات والأزمنة السردية المخبأة في طي الكلمات؛ حيث تنرز لنئ لنا نظرة الثناعر

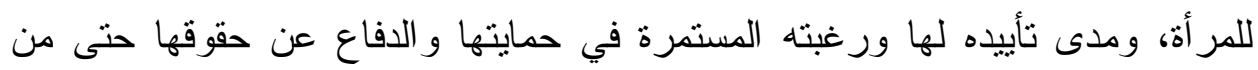
التاريخ الذي طالما حفظ لنا حكايا اضطهاد المرأة وظلمها و التعدي المتعدد الأشكال عليها وفي مختلف العصور . -المر أة امتز اج بالحياة ما بين صورة الذكورة و الأنوثة و الغريزة الهائمة ما بين الجوع

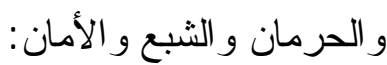

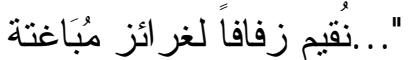

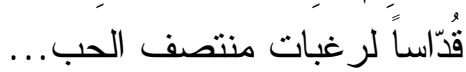

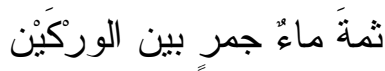

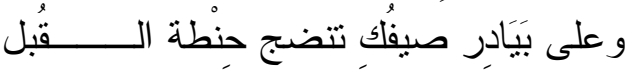
سأخال 'أنك النهر و أنني السرير أنك الماء و أنني الضفاف

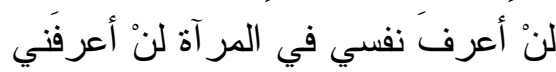
أنا الآن سوَاي

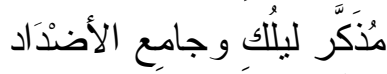

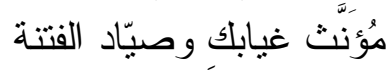
ليجتاحَني صيفلك كضيف وقِح

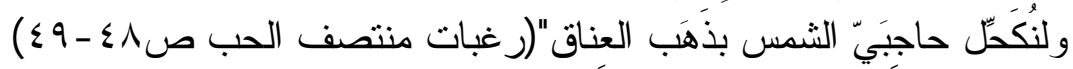
كل هذه الرغبات المفاجئة تحتشد في بقعة ضوء طبعها تلاقي روحي الرجل الرجات

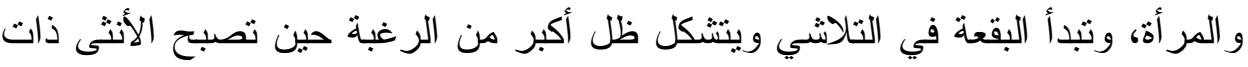

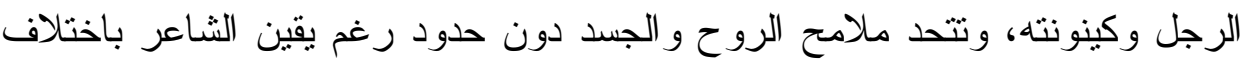

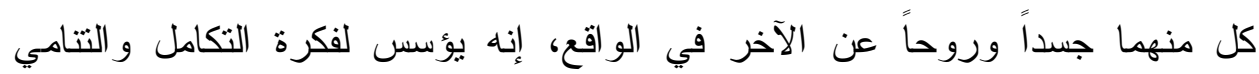
و التو افق التام بين قطبي هذا الاختلاف البيّن ليحقق نوع مميز جداً من المصالحة التي ترضي ذاته وتشبعها: - ون 
"جسمي سِكّة انتظارك أيضاً

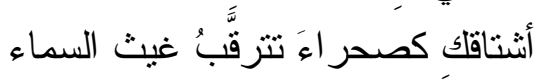
كقبيلة أضناها العطش

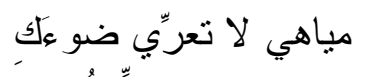

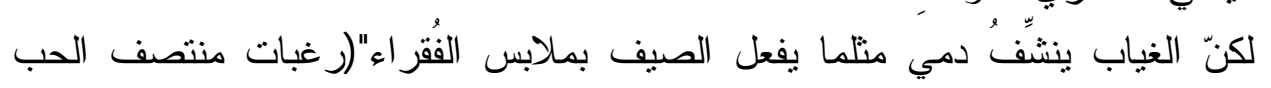
ص ص هذا فعل الغياب و الانفصال عن الأنثى؛ أما اللقاء فيغير خارطة الذات تماماً، لتكون موئل الفرح و النقاء والمتعة النضرة في رحاب الحياة، وعبر تغير الأفي؛ الذات فئاء وتفاعلها سيغدو الكون عالماً أرحب و أكثر شسو عاً لطموحات الذات في تحقيق وجودها:

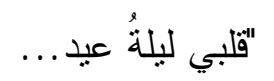

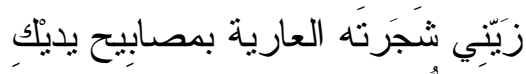

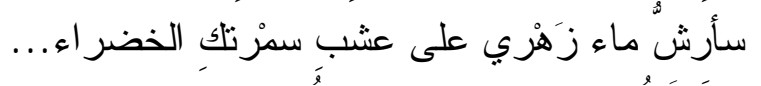

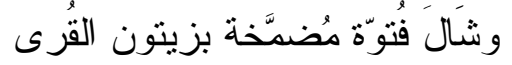

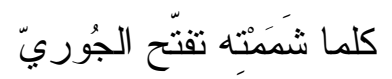

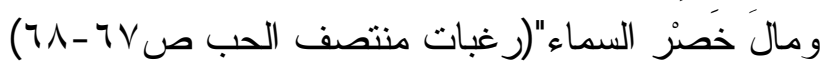

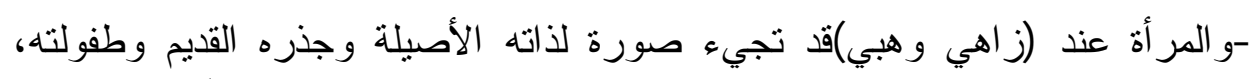

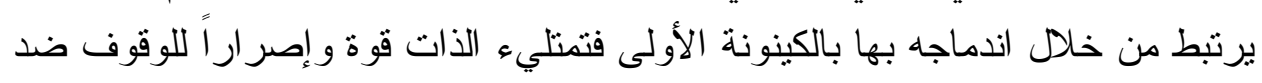

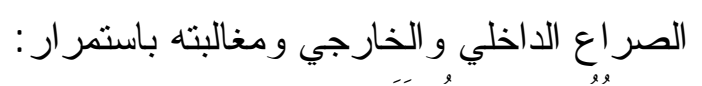

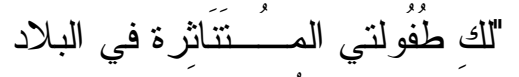

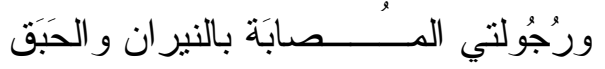
للك أغنيتي ولحنُ طِيْن عنيق ل...

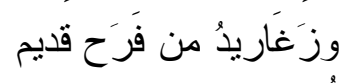

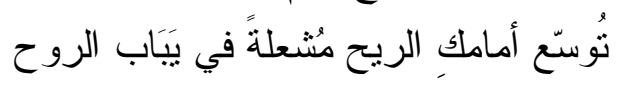
ألف حريق

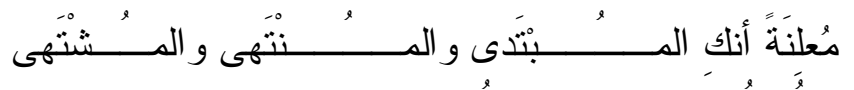

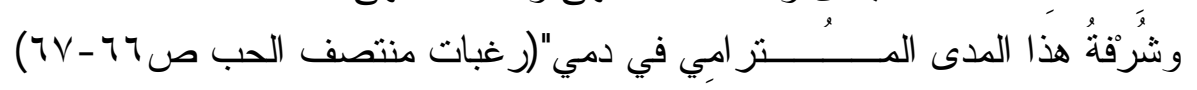


لاريب أنها لحظة حاسمة في تاريخ كل ذات؛ فالأنثى كما يبدو هي مصدر التقائه بنفسه وبأصوله في رحلة البحث المريرة التي يقضيها كل إنسان لتحقيق ذاته وتوكيد وجودها عبر هذا الكون الفسيح والأزمنة غير المنتهية. -و المر أة هي الآخر البعيد الجمعي الذي تتصلالح معه ذات الثاعر في لحظات المرور الجميل على مدن التاريخ النبيل: التهريل

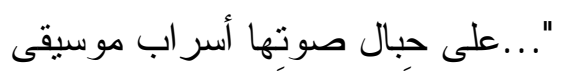

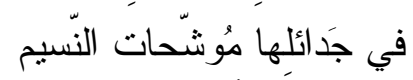

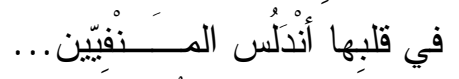

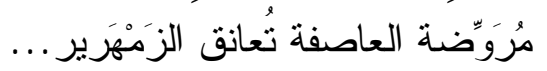

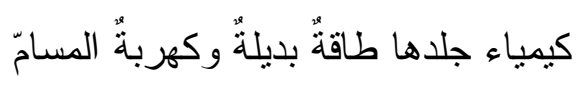

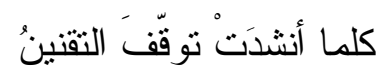

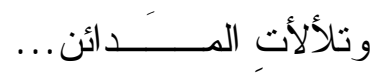

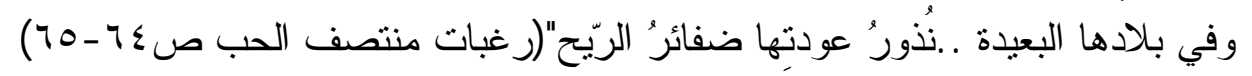
-الأنثى هي ذاته المتحولة المقابلة للسام و الأمان، في حين أن ذاته الأصلية هي الآخر التراتِ

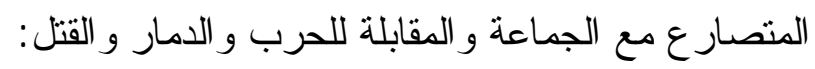

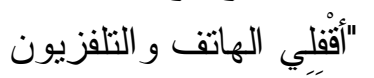

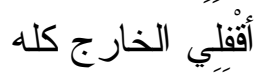

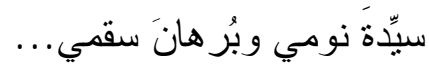
في الخار ج مُقَاتِلون وقَتَلَّة

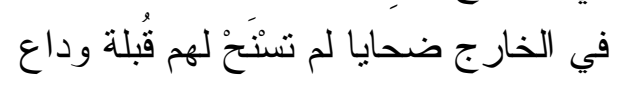
هيا إذن

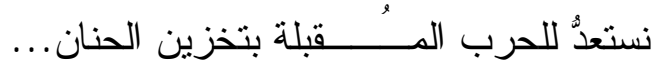

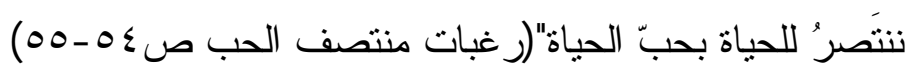

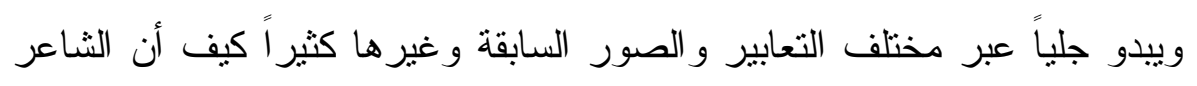

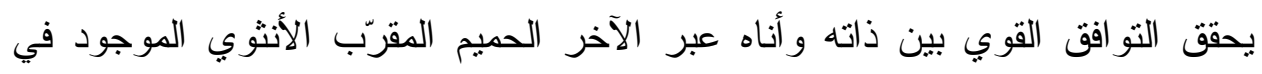

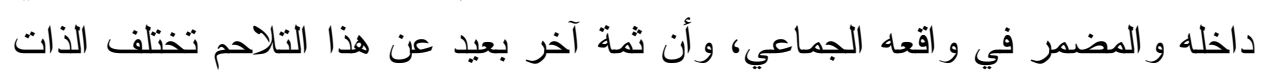
في تقدير ه ما بين(مقاتلون وقتلة/ ضدحايا) . 
وكيف ستككون هزيمة الآخر المعادي؟ وعلى بد من ؟ هناك أنتى وذات تعانقها

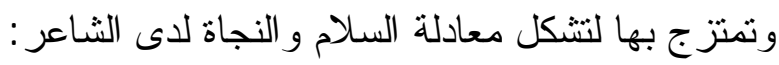

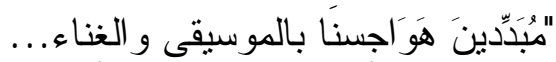

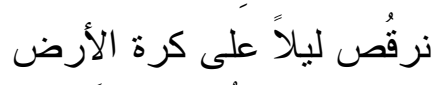

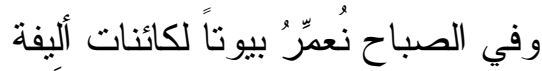

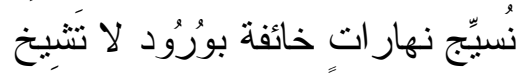

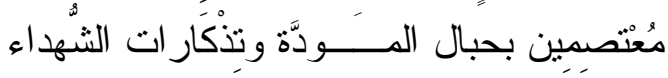
نقول للحرب ابتّعدي، ابْتعدي نحذف الرَّاء القاتلةً

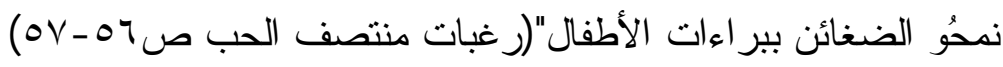

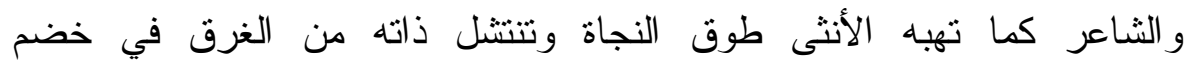

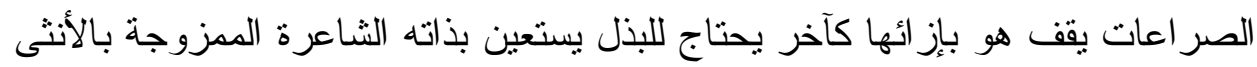

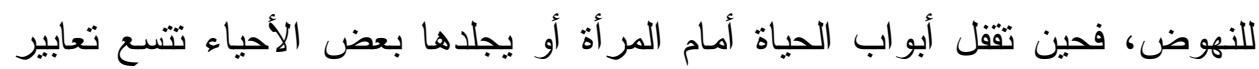

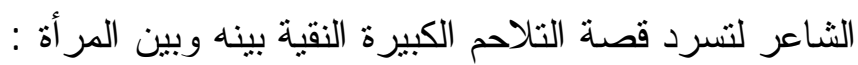
"كيف لكَمَان أن يتجهُّة

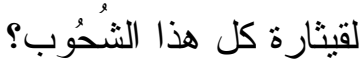
لنَ آكلَ أناملي ندماً

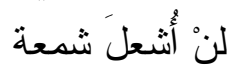
سأهبُكِ أضلعي لنعي وسكينة الأسىى في صدري عو اطف مُزمنة وزو ابعُ غفرْ ان سأحتضنك كَثتاء حنون بدمعة خضر اء

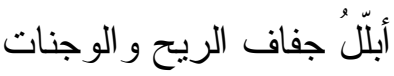

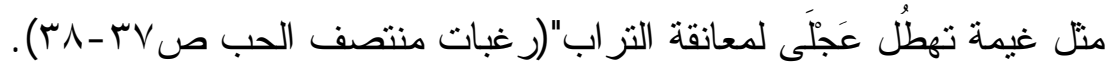
"خلقكَمَا لتكونا معاً 


\section{من ملامح الذات وصورة الآخر في نماذج من شعر (زاهي وهبي) دكتورة/ أمل عبد الله زين العابدين}

$$
\begin{aligned}
& \text { بلا شرط، بلا قيد } \\
& \text { بلا حبْر ، بلا ورَرَق بِ } \\
& \text { تجلَّى في الحب لحن } \\
& \text { في الحب تجلَّى في } \\
& \text { لو شاءكَّ وحيداً لفعل } \\
& \text { لكنكَ لا ترتعشُ 'إلا لها }
\end{aligned}
$$

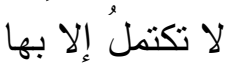

$$
\begin{aligned}
& \text { أنتما مُفْرَدَ مُعتَّى إَّى } \\
& \text { أنتما و احد أحد .... } \\
& \text { لا تخجل بنقصانكَ }
\end{aligned}
$$

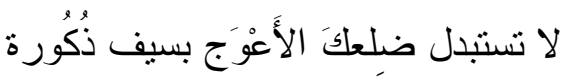

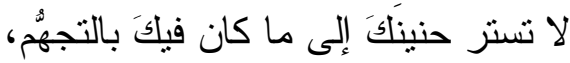

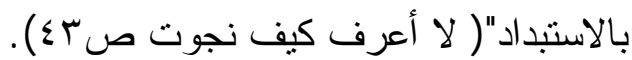

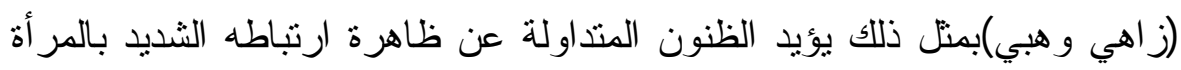
بسبب شغفه بو الدته فيما يتقارب مع العقدة الأوديبية، وهو أمر ينعكس إيجابياً على ذاته

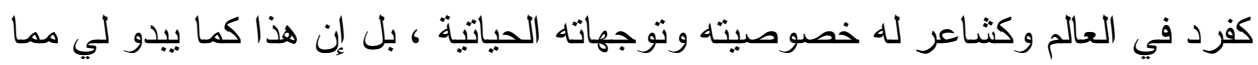
يخلصه من عقدة الآخر المعادي أو شبه المعاكس؛ فالآخرين يحاولون دائماً تضخيم الفجوة بين كينونة الرجل و المرأة مع التشكيك في وهمية التمازج الناجح بينهما في الحياة:

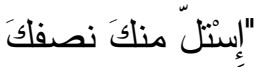

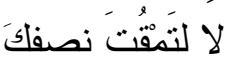

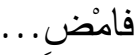

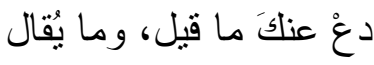

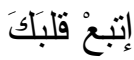

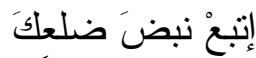
إذهبْ إليها ...

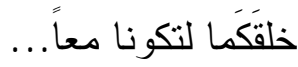




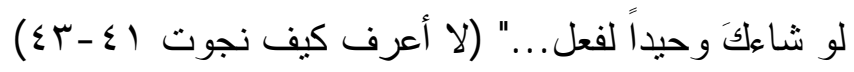

وحديثه و امتز اجه مع كيان الأنثى ليس دفاعاً عنها بقدر ما هو إيمان كامل بقدرتها

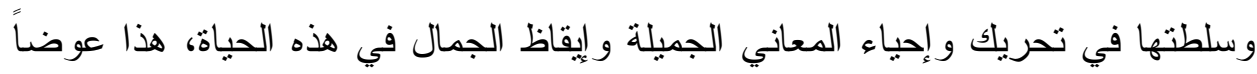
عن تضخيم ذاته بانتمائه لذات الآخر الذي هو من وجهة نظره أكبر قيمة وهي

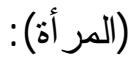

$$
\begin{aligned}
& \text { "كثيرة، كثيرة" } \\
& \text { لا تحتاجين برهاناً و لا أُعجوبة ـ... }
\end{aligned}
$$

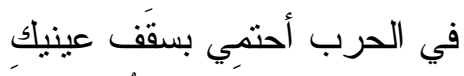

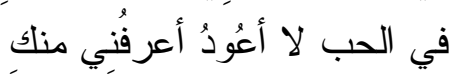

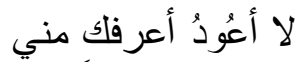

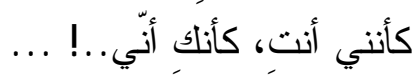

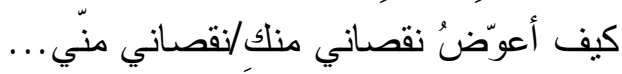

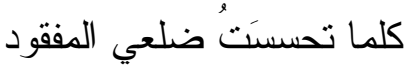

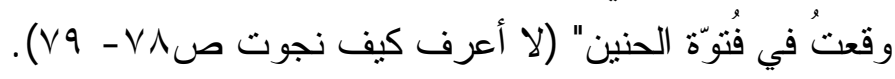

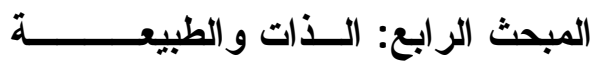

للطبيعة صوتها العفوي الطليق في أجواء النصوص العربية وغير العربية، فهي

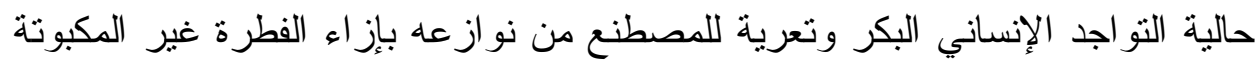
أو المقننة، إذ نأتي الطبيعة لدى غالبية الثعر اء صورة للتحرر وفلك القيود واجنياز

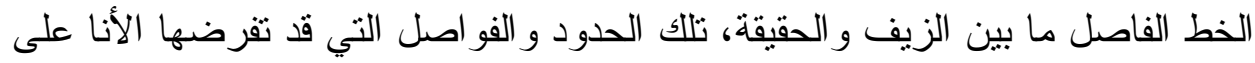
الذات أو يفرضها الآخر بشتى صوره(القريب الفردي أو البعيد الجمعي) بوصمه شريكاً

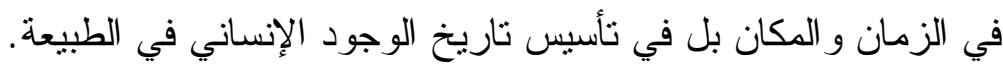

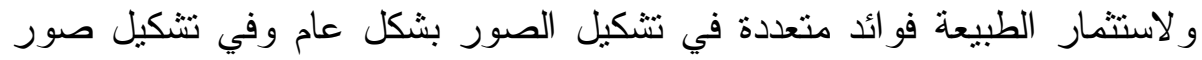

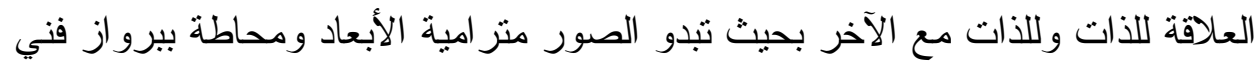

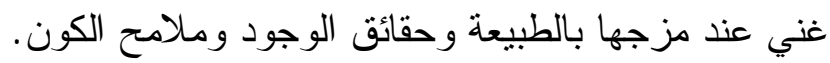

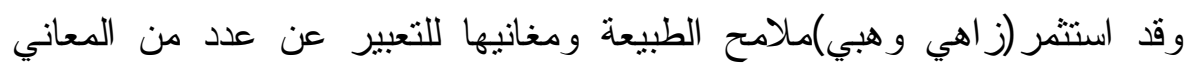
الكونية وعلاقة الإنسان بالحياة وحقائقها من جهة وحقيقة وجوده بها من جهة أخرى، إنى 


\section{من ملامج الذات وصورة الآخر في نماذج من شعر (زاهي وهبي) دكتورة/ أمل عبل الله زين العابلين}

فنجده هنا يعبر عن الرغبة الملحّة لدى الإنسان في العودة للجذر الدافيءو الأصل القيّم النقي لكل البشر : البش "لا تصدق أنه يكره الفرح، يحب السو اد إلى هذا الحد منربصاً بك كل حين أنه بكره

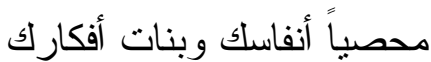

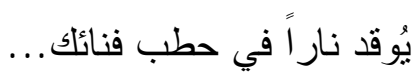

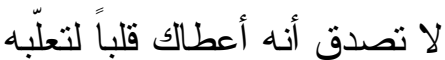

شهوة لتطفئها بصر اً لتعيش كفيفاً

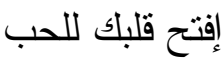
ذر اعيك للمدى إفتح قلبك للموسيقى صدرك للغرباء... أحب قدميك كي لا تخذلك الطريق إذهب حيث شئت، حيث نتشاء كل الجهات تؤدي إليه

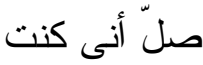

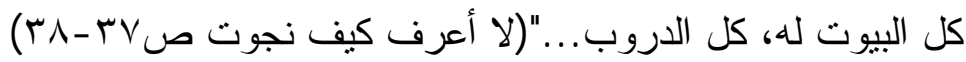
إنه حديث الذات مع الأنا المنشق المعارض، صوت الاعره الذات كصوت الضمير الحي ويقوم بدور المعلم و المهذبِ و المربي، حديث عن اله الواحد الذي هو أصل كل شيء

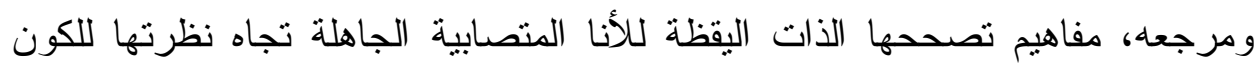

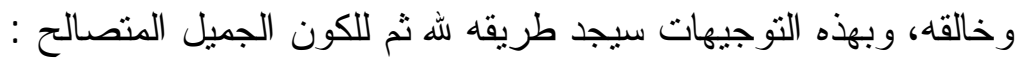
"إفتح كفيك للمطر ، للعناق وخده لأن عينيك لأحسن تقويم لا تصدق أنه يحب الذبائح أكثر

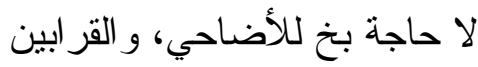

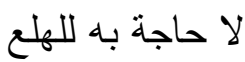




$$
\begin{aligned}
& \text { هو الذي آمنك من خوف و أطعمك من جوع } \\
& \text { جعلك في الأرض خليفة } \\
& \text { لتزر ع وتحصد وترفع الصوت }
\end{aligned}
$$

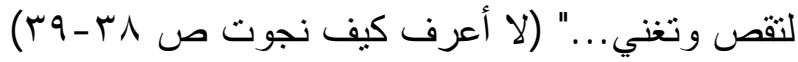

الصور المشعة نور اً بمعرفة الله الخالق وعظمة دلائل وجوده الكامل في هذا الكون

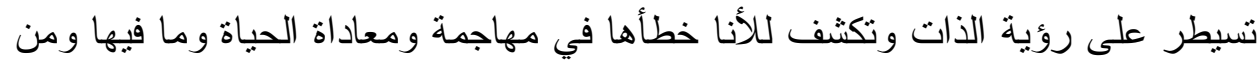
فيها، هذا العداء الذي نتج عنه تدمير جمال الطبيعة وملامح الحياة النقية التي وهبها لنا الله و استخلفنا عليها وفيها: "ألبست شمسه المبتسمة كل صباح

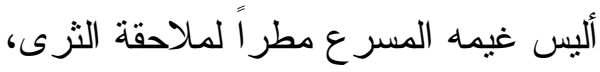

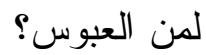
لم الضغائن؟ علام يقاتل الذين خلقهم شعوباً لتعارفو ا؟ علام يتقانل أخوة التر اب؟ لابن لا تصدق أنه يحب المنتشين بالدماء... لا تكن سجناً أو جداراً لا تكن عاصفة حمقاء كن نهراً كن جسر اً لمشاة الريح

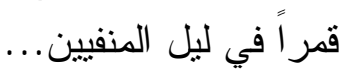
لا تصدق أنه نصير الأنصاب و الطغاة وسع كرسيه السماو ات و الأرض لأهير لانه

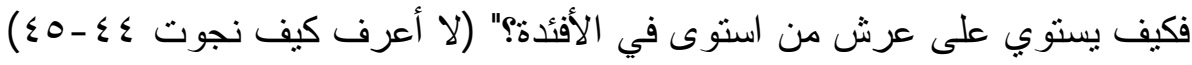

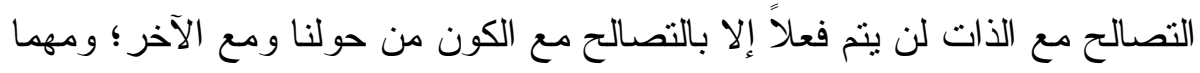

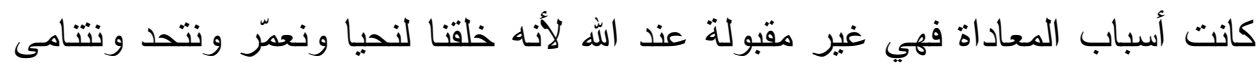
بجلال لا نتقاتل وندمز فنضمحل، كيف إذن يتم هذا التصالح الطريق سهل جداً وفق

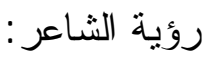




$$
\text { أحب ما خلق أتحبه ما أعطاك" (لا أعرف كيف نجوت ص اء ) }
$$

ومن المعالم البارزة في صور (زاهي وهبي) التي يمزج فيها بين الذات و الطبيعة و الكون حديثه عن الصراع الحضاري وتعديات العولمة وقتل الفكر المستنير وهنك ونك حصون العاطفة البشرية، فيجيء تفكيره المستمر في المصير و المآل للكون وللإنسان إثر هذه التضخمات القاتلة في حياتتا العصرية على نحو عميق جداً: "خصرك الصيفي يبدد صقيع العولمة هده

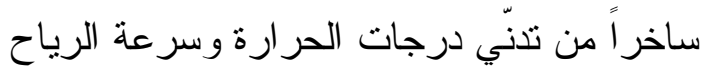

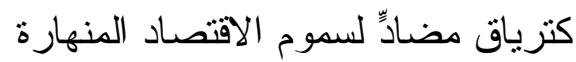

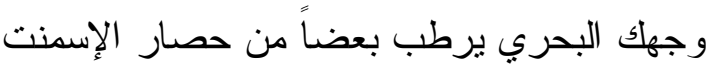

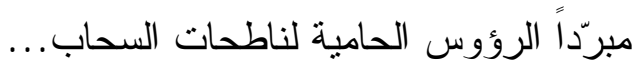

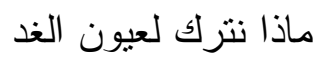
لأطفال يكبرون تحت ظلاذل لـون الباطون المسلّح

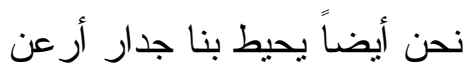

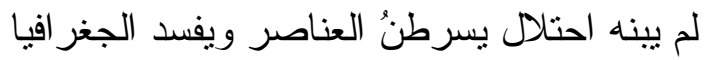

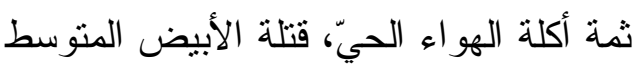

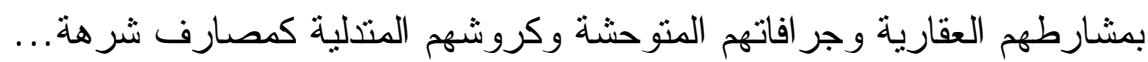
كلما اشتد الحصار اتسعت نو افذ عينيك كلك

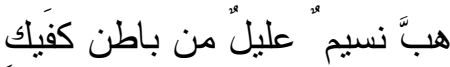

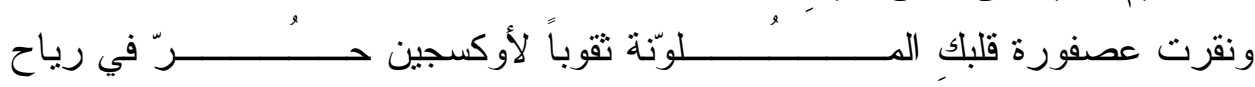

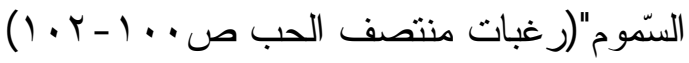
إننا لن ندرك حجم الفارق بين حقيقة وجود ذوانتا في هذا الكون ووظائفنا فيه إلا

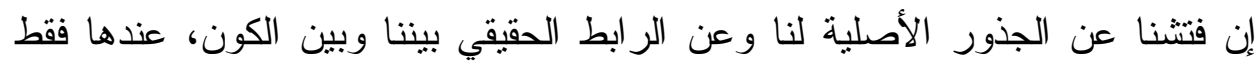
ستضخح قسوة الواقع الحضاري على الإنسانية ككل ومدى تصادمه مع الجذر الكوني 
العميق للبشر، وفي ذواتتا مهرب وملجأ من حصار الحضارة و المادة و المصالح

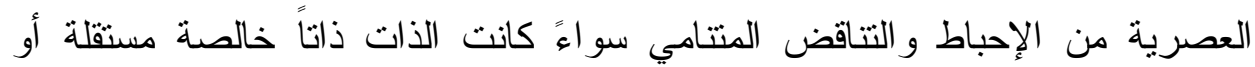
منقابلة مع الأنثى كرمز للخصب والفطرة والحقيقة النقية كما يبدو لدى الثاعر (ز اهي ورهب): "في زحمة السير ولهاث الميكانيك

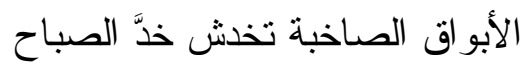

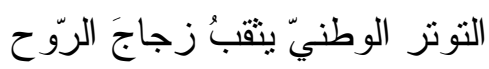
التسابق محمومٌ نحو هدف ساقط أصلاً

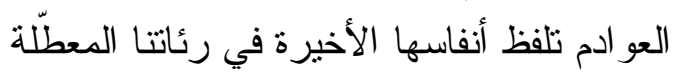
السائقون يتبادلون الثتائم و النكات البذيئة ليس لي في هذا العر اء الآلي سوى استحضارك لئك

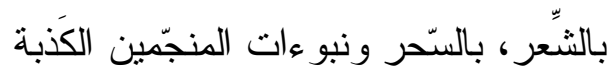

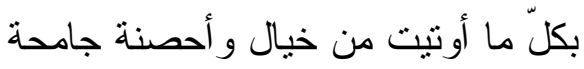

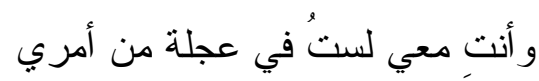

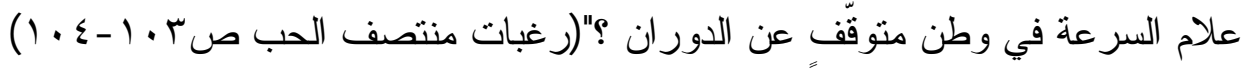
اللهاث، السرعة، التسابق، التوتز بالفعل صنوف صورة عن العراء الآلي كما سماها

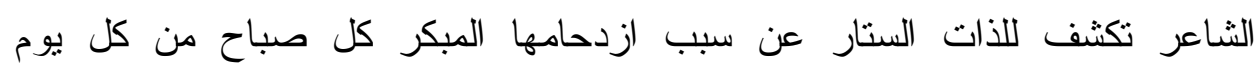
بالشحنات السالبة تجاه الآخرين وكل ما حولها، عدا ذا الآخر القريب اللصيق بالذات

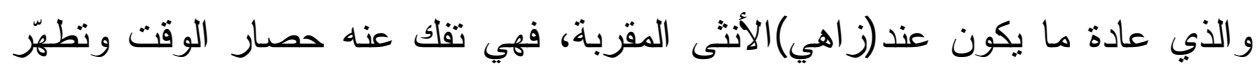
أجو اهه من التلوث العصري وترحل به على ألى أحصنة الخيال لعالم أبطأ و أقل ازدحاماً

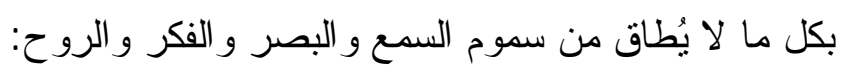
"لا الرصاصة تقتل فكرة

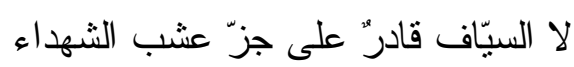
كلما عرش كالدو الي تسدين ثقوب الصدر بضحكة من سنونو

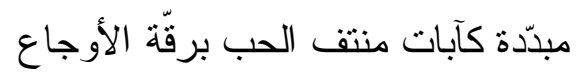




\section{من ملامح الذات وصورة الآخر في نماذج من شعر (زاهي وهبي) دكتورة/ أمل عبد الله زين العابدين}

بيدين مطمئنتين تمسحين عرَق الاحتلال عن جبين دولة مؤجّلة ..."(رغبات منتصف

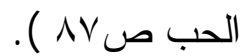

"في الخارج مقاتلون وقتلة

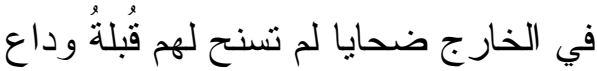
هيا إذاً

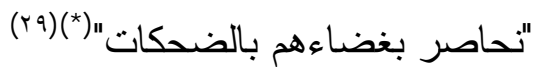
ليس الحب خيمة زرقاء

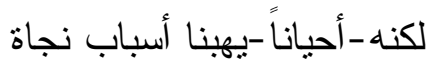
ننتصر للحياة بحب الحياة

مبددين هو اجسنا بالموسيقى و الغناء بنار أليفة في ليالي البرد وصقيع الفتن ...

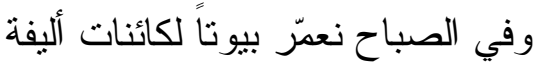
نسيّج نهار ات خائفة بورود لا تشيخ نيخ لنيخ معتصمين بحبال المودة وتذكار ات الثهداء نقول للحرب ابتعدي، ابتعدي نحذف الر اء القاتلة نمحو الضغائن ببر اءات الأطفال الحب ممحاة الأسىى علة الشروق وحلم الجنود بالعودة سالمين

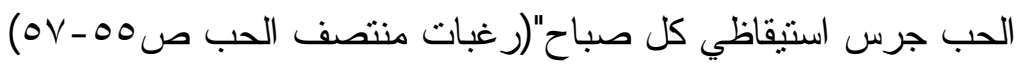
وللحرب دورها في تشكيل حقيقة العصر الذي ينمحي فيه سلام الذات و الآخر القريب ويتعاظم فيه حقدها وصدامها مع الآخر البعيد المعادي بصورة فرد فئ أو أمة فئ

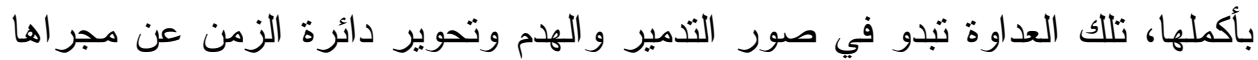

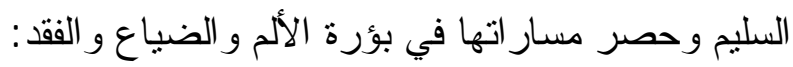

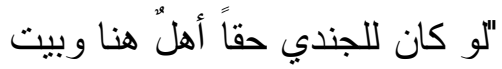
وطفولة من عشب وبر اءات 


$$
\begin{aligned}
& \text { لو كان للجندي شجرة عائلة } \\
& \text { وغرسة على اسم شقيقته الصغرى سجره عاله } \\
& \text { لو كان لله موعد عاطفي بعد صلاة العشاء } \\
& \text { أكان ليضغط بهذه السهولة على لـ الزناد؟.... }
\end{aligned}
$$

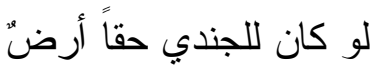

$$
\begin{aligned}
& \text { وخارطة عتيقة ورثها عن أبيه .... } \\
& \text { و وأسلاف عاشو ا بيننا } \\
& \text { تقاسمو الحنطة و النهر و الزمهرير ... }
\end{aligned}
$$

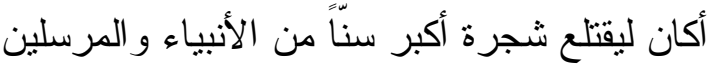

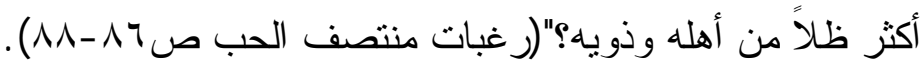

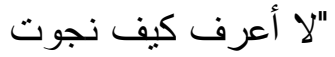

$$
\begin{aligned}
& \text { ذاكرتي مصابة بالرصاص } \\
& \text { قلبي مقام حجاز }
\end{aligned}
$$$$
\text { على مرمى قبلة فجوات قذائف }
$$$$
\text { على مرمى قذيفة أثر لقاء }
$$

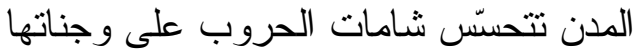

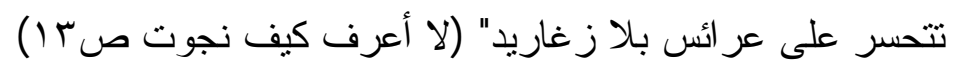

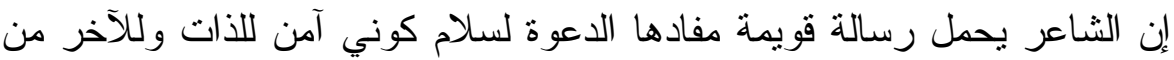

خلال إحاطة العلاقة بين ذاته والآخر بسياج مشروط بالتصالح المادي والروحي،

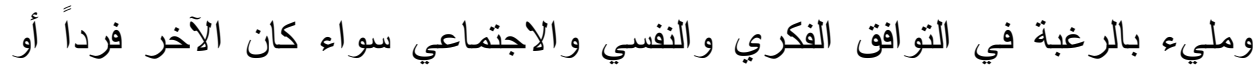
جماعة، أو منظومة كلية متكاملة تشمل جميع مكنونات هذا الكون ومحتوياته : "لمن العبوس؟

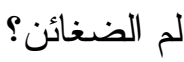
علام يتقاتل الذين خلقهم شعوباً وقبائل ليتعارفو ا؟ علام يتقانل أخوة التراب؟ لا تصدق أنه يحب المنتشين بالدماء أنوة

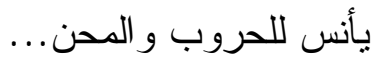


إفتح قلبك للعابرين، للغرباء

$$
\text { كن شرفة، حديقة }
$$

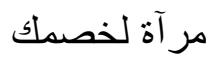

لا لا تكن سجناً أو جداراً

لا تكن عاصفة حمقاء

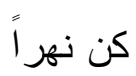

كن جسراً لمشاة الريح

قمر اً في ليل المنفيين

فر اثنة تهزم بجناحيها الأنو اء لهين

لا تصدق أنه نصير الأنصاب و الطغاة...

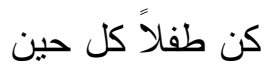

لا يضيرك دمع أو انحناء، ضعف طئ أو هشاشة

كن عثبة بريئة

سحابة حب في صيف الأشواق

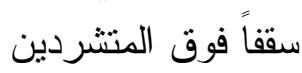

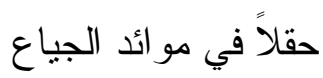
رغيفاً أو سنبلة في أند

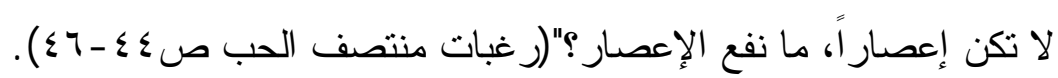

الصور تتشكل كحبات ألم في عنقود كبير هو (الذات)، الصور المنو الية نو الياً

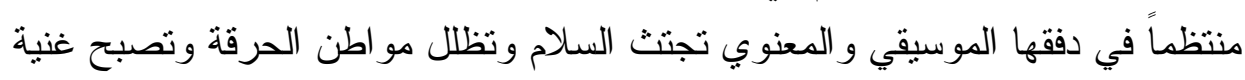

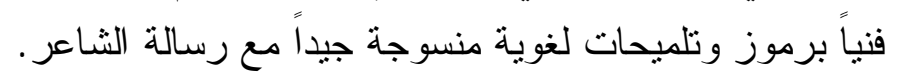


من خلال رحلة البحث في ملامح الذات وصورة الآخر في نماذج من شعر (زاهي وهبي)، رصدت عدة نقاط من أهمها:

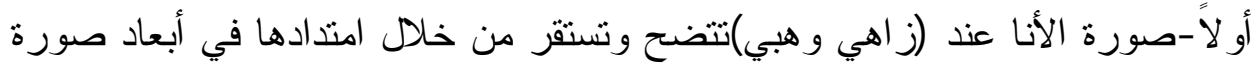

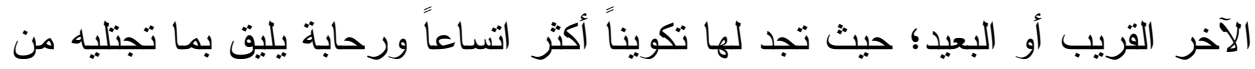

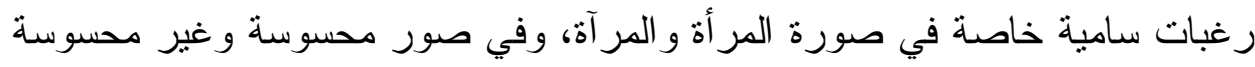

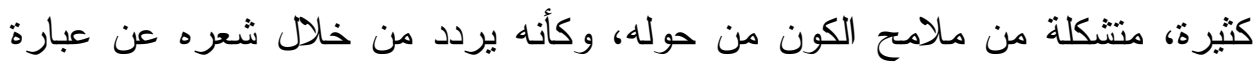

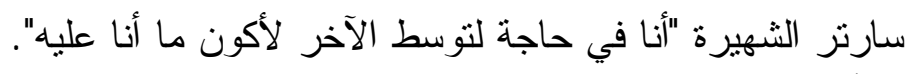

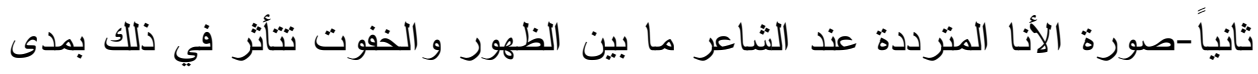

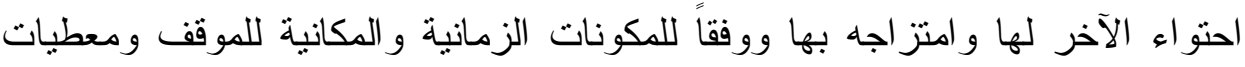

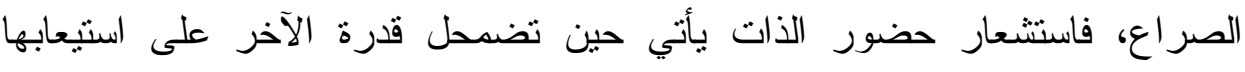

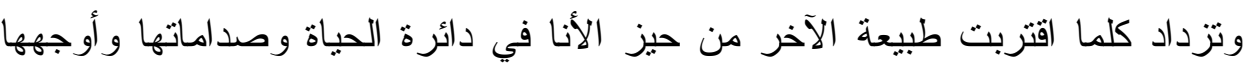
الأكثر تعقيداً.

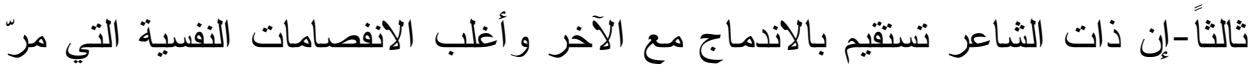

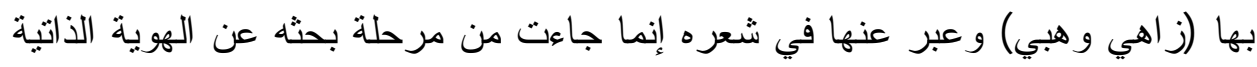

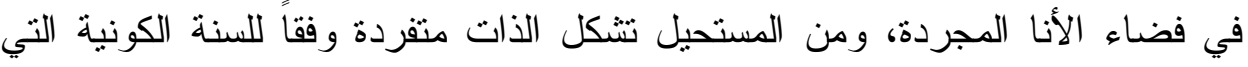

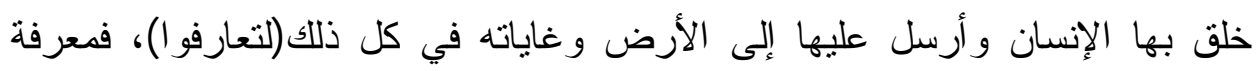

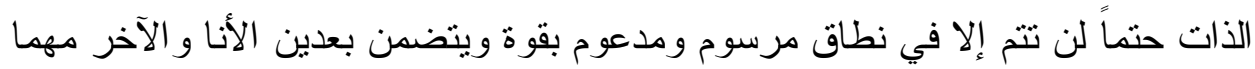

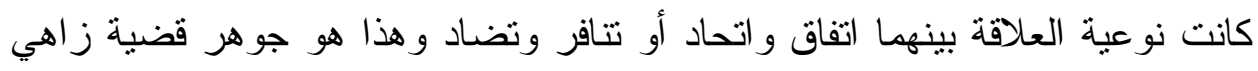

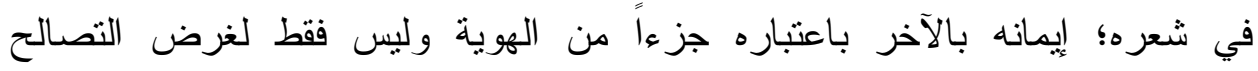

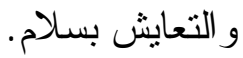
رابعاً -أن الآخر يسهم بدور مهم في فهمنا للمعتقات و والقيم و الدين و الفلسفة والهوية

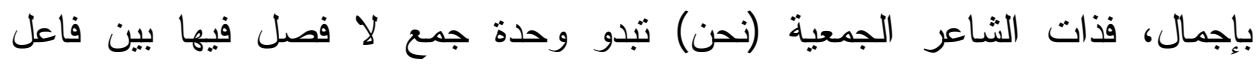

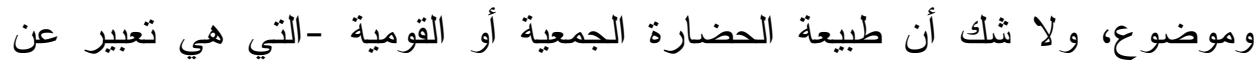

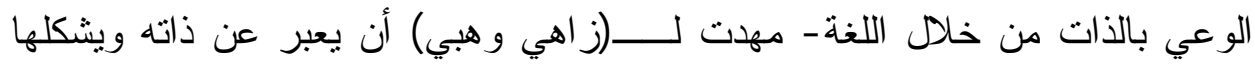

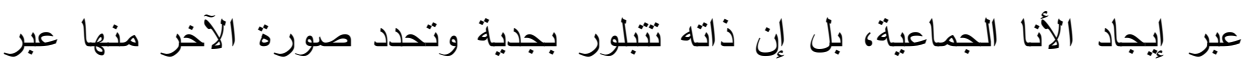

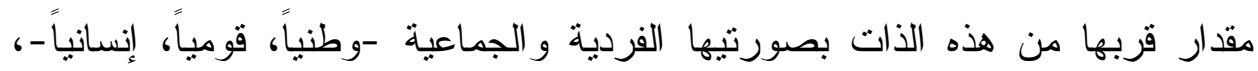




\section{من ملامج الذات وصورة الآخر في نماذج من شعر (زاهي وهبي) دكتورة/ أمل عبل الله زين العابلين}

وكذلك بحسب تقاربها مع رؤية الثاعر لكل جانب من جوانب الحياة ومواقفها، ويبدو جلياً مدى ثبات هذه الرؤية في تحديد موقف الثاعر من ذاته وما حوله في تجربة

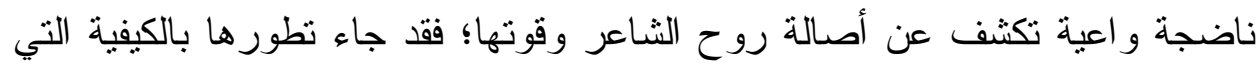
تحافظ على الرؤية الأعم والأشمل لدى (زاهي وهبي) كاشفة عن تراعة اكم تجاربه

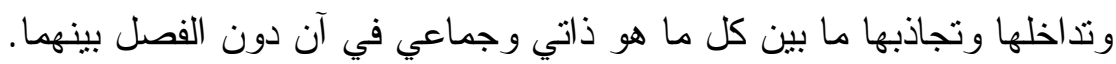

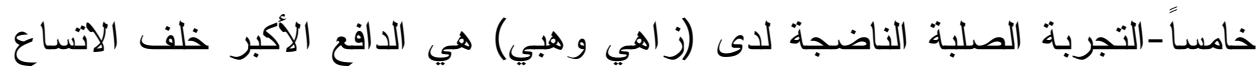

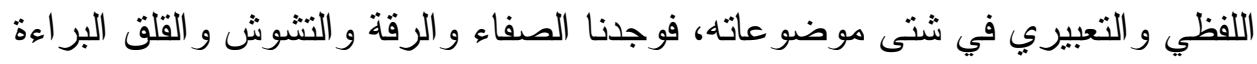
و الثر اسة ومتتاقضات مختلفة تحيي في معمارية نصوصه الحسَّ الدر امي المؤثر فنر اه

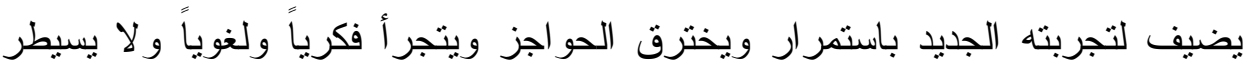
عليه نمط أو تحدّه خطوط لا في لغته و لا في مضامينه .

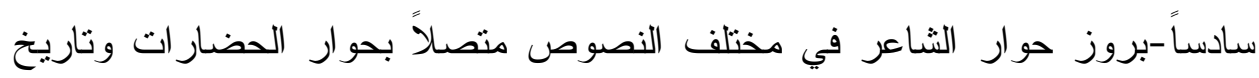
ونزاث أمته، وأبلغ ما كثف ذللك في رؤيته للآخر تتاصاته التزاثية المنوعة الكثيرة،

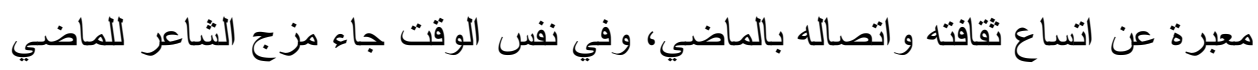

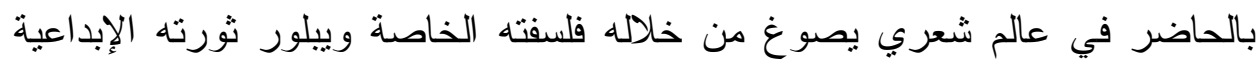

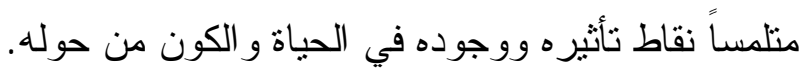

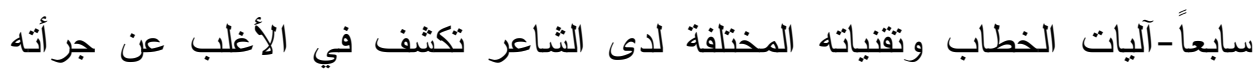
و اهتمامه بجمعها وتكوينها وتوظيفها لتعرية ملامح الذات مهما كانت صور ها مشوشة ونة

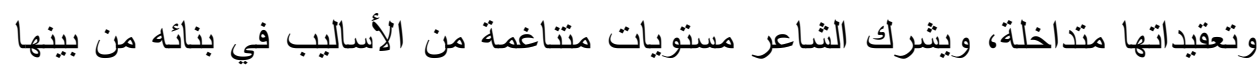

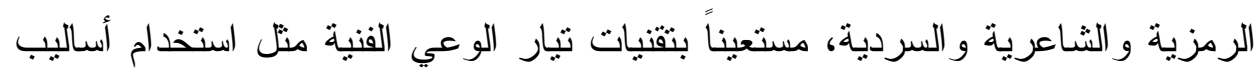

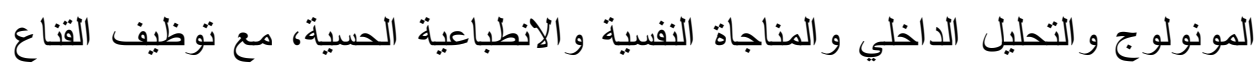

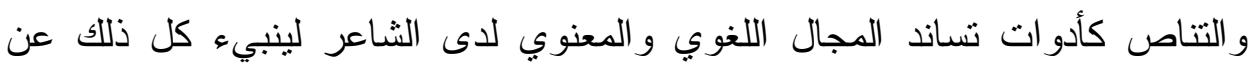
مقدرته على دمج المعطيات الداخلية و الخارجية لدعم خصوصية تجربته ورؤيته حول

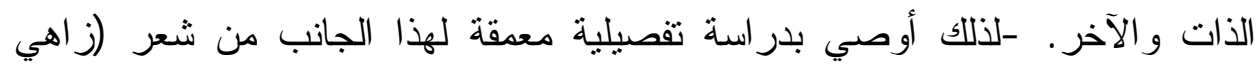

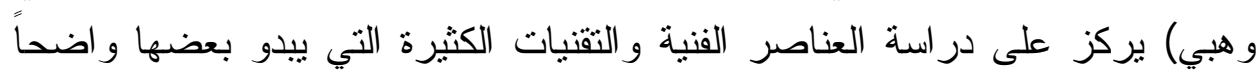

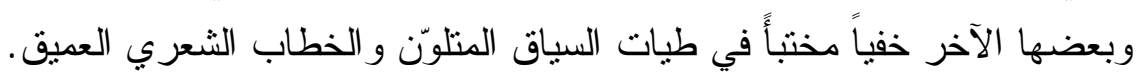


1 -المعجم الوسيط/إخراج:إير اهيم مصطفى أحمد الزيات و آخرون،المكتبة الإسلامية -إستانبول تركيا، طץ -

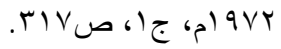

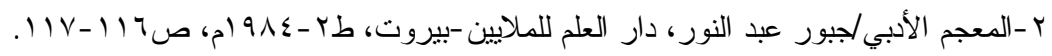

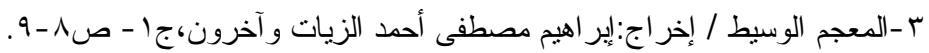

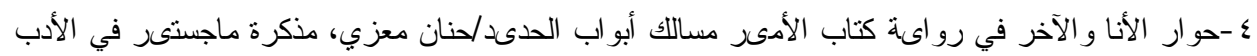

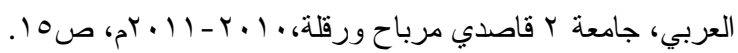

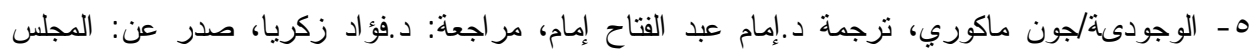

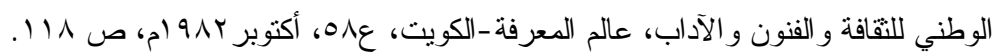

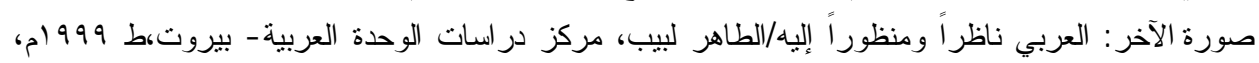

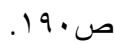

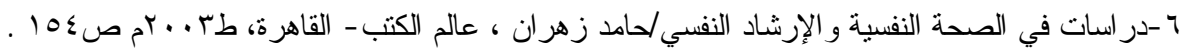

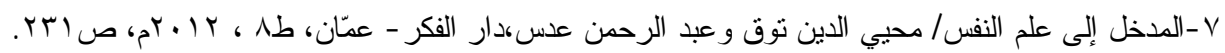

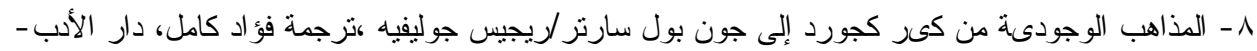

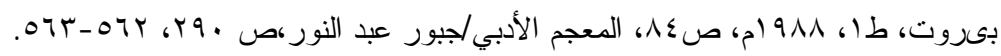

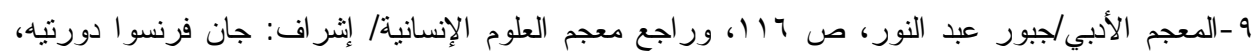

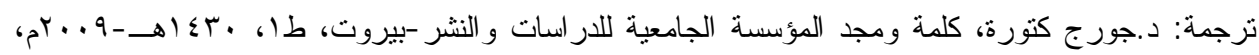
ص ص 9.

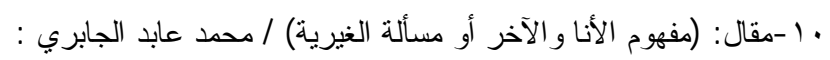

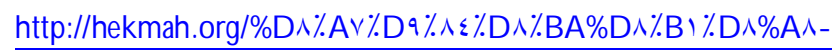

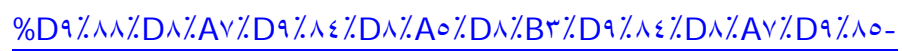

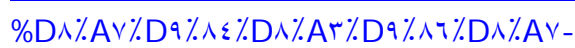

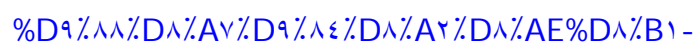

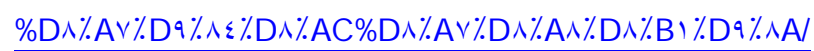

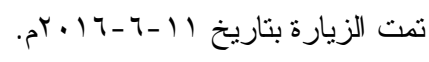

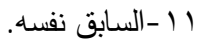

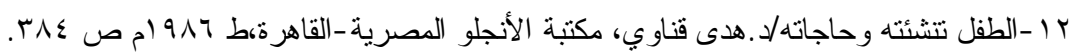

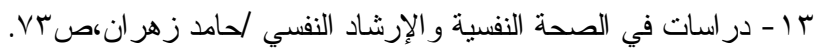

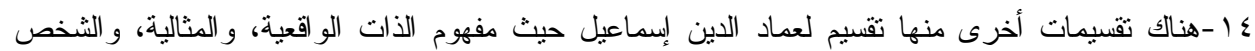

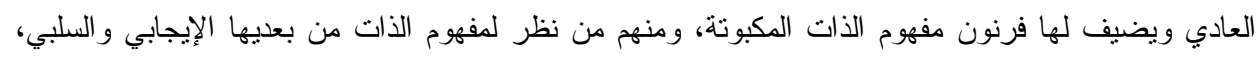

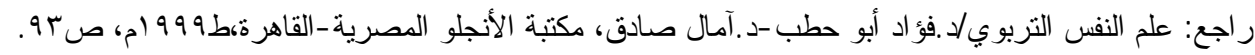

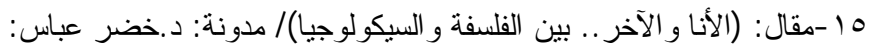
https:/drabbass. wordpress. com/r.1r/:1/17/ 


\section{من ملامج الذات وصورة الآخر في نماذج من شعر (زاهي وهبي) دكتورة/ أمل عبل الله زين العابلين}

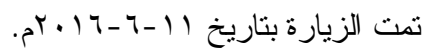

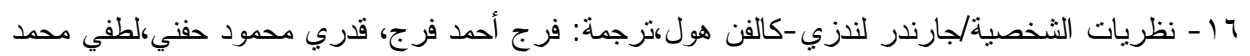

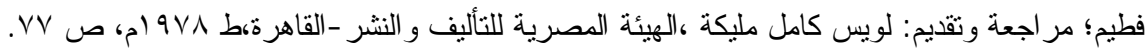

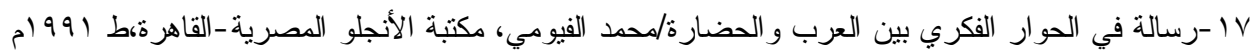
ص

1 ا - التخلف الاجتماعي مدخل الى سيكولوجية الإنسان المقهور /د مصطفى حجازي، المركز الثقافي العربي -

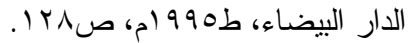
9 19 ر اجعت في سيرته موقع ويكيبيديا (الموسو عة الحرة):

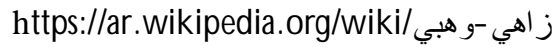

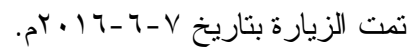
وقد حاولت جاهدة التواصل مع الثاعر ولم يتجاوب، و انقضى الوقت فاكتفيت بما وجدت عنه في مو اقع التواصل و وعبر وسائل الإعلام. •r - من مقال: (تشكلات الأنا والآخر في شعر : نادر هدى)/ د.طلاد الطاهر قطبي: www.alrai. com/print.html

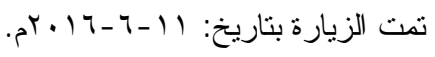

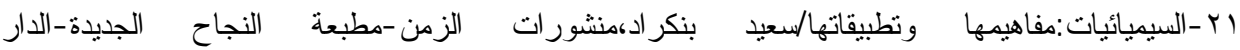

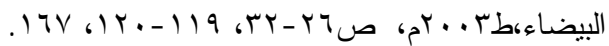
r r -هذه بالفعل وجهة نظر الثاعر (ز اهي وهبي) التي عبّر عنها كثير اً في لقاءات ومقابلات صحفية منها لقاء في مجلة زهرة بعنو ان(أضاهي المر أة أنوثة)بعد صدور ديو انها(أضاهيك أنوثثة)ويأني هذا الديوان مكانثفة فنية عميقة

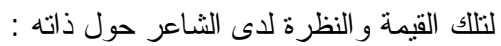

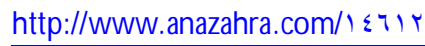

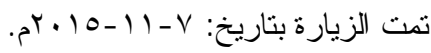

rr - مقال :(المر آة)/ عدد من الكتاب :العريس، شوقي بزيع، نجاح طلعت، دارين صالح، مجلة القافلة الثقافية: http://qafilah.com/ar/

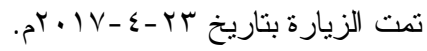
ع r - السابق نفسه مقال:(المرآة)/ عدد من الكتاب :العريس، شوفي بزيع، نجاح طلعت، دارين صالح، مجلة

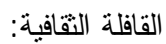
http://qafilah.com/ar/

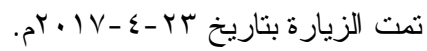

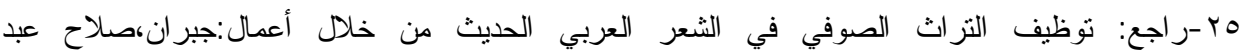

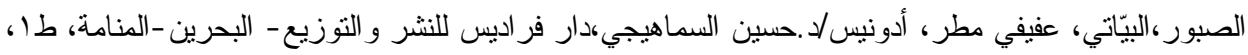

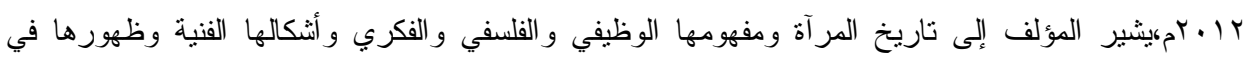


دراسة تطبيقية لعدد من شعر اء الداثة، باعتبارها صورة للإبداع الثعري وتحركاته في الجانب المعرفي

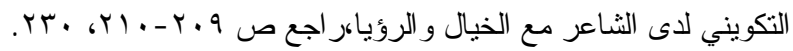

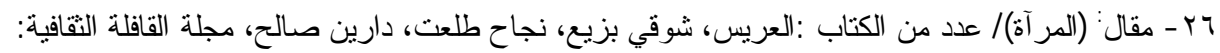
http://qafilah.com/ar/

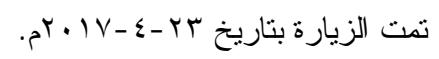

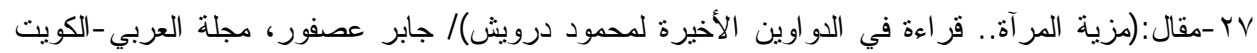
http://www. arabicstory.net/forum/index. php?showtopic=9 / r r

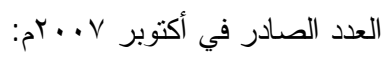

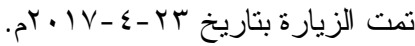
وراجع: اتجاهات الثعر العربي المعاصر لا..إحسان عباس، المجلس الوطني للثقافة والفنون و الآداب، عالم

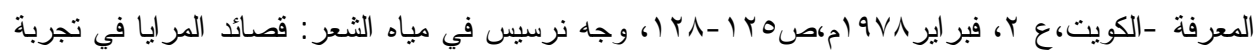

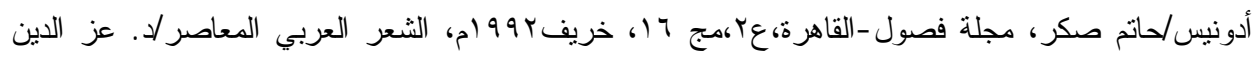

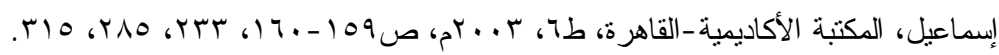

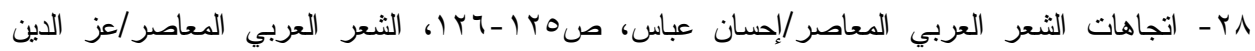

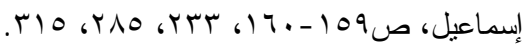

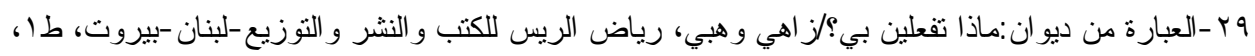

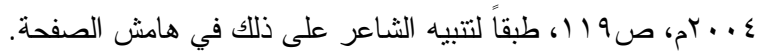

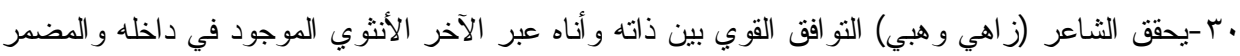

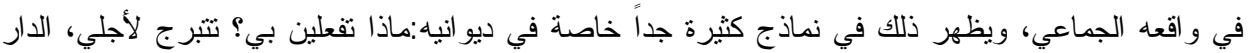

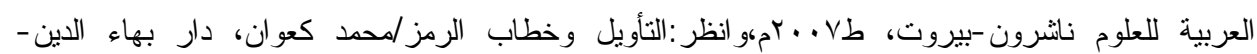

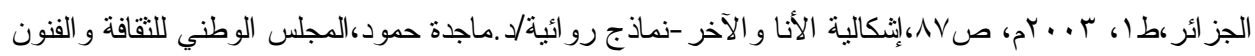

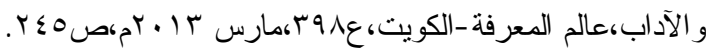




\section{من ملامج الذات وصورة الآخر في نماذج من شعر (زاهي وهبي) دكتورة/ أمل عبل الله زين العابلين}

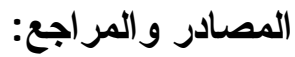

-مصادر نصية:

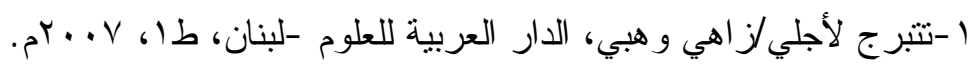

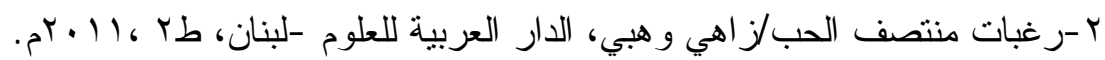

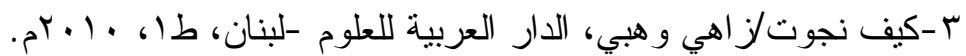

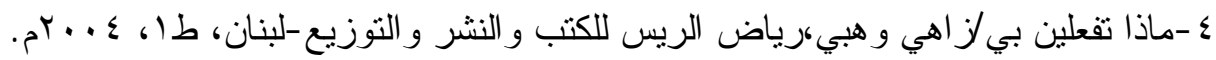
مراجع إجرائية نقدية

ه -اتجاهات الشعر العربي المعاصر /د إحسان عباس، المجلس الوطني للثقافة و الفنون

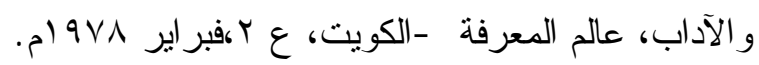

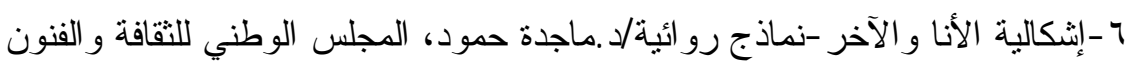

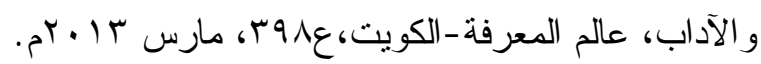

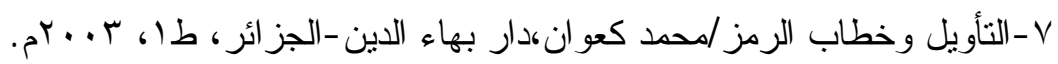

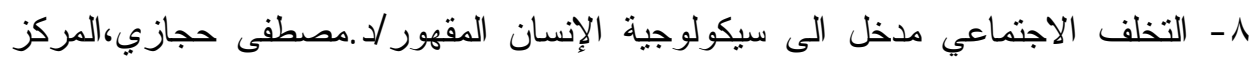

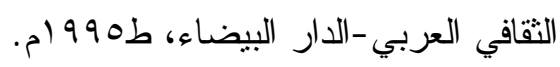

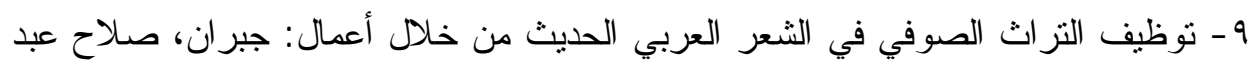

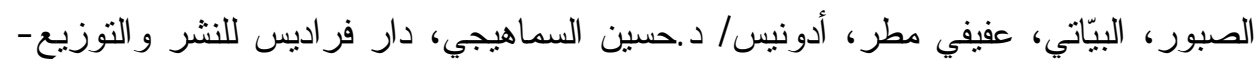

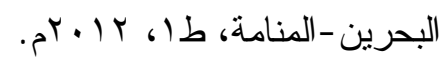
• ا حوار الأنا والآخر، في روائة كتاب الأمىر مسالك أبواب الحدىد/حنان معزي،مذكرة

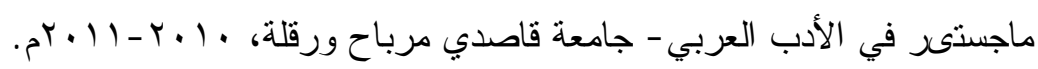

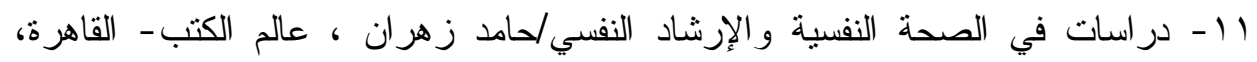

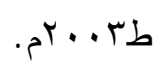
r ا - رسالة في الحوار الفكري بين العرب و الحضارة/محمد الفيومي،مكتبة الأنجلو المصرية، b

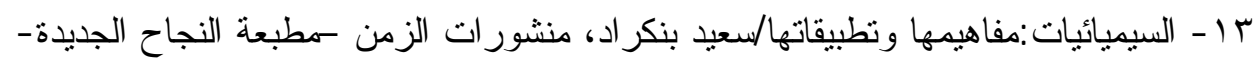
الدار البيضاء، ط ب . . r.

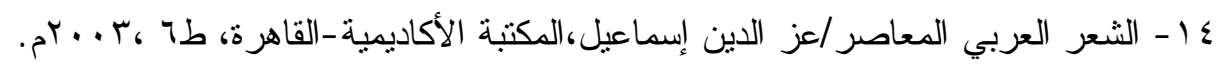


ه 1 حورة الآخر : العربي ناظراً ومنظوراً إليه/الطاهر لبيب، مركز دراسات الوحدة العربية -

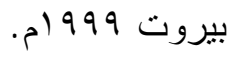

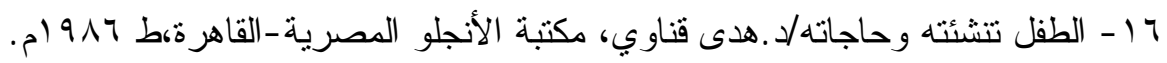

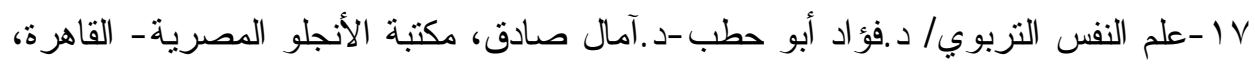
. م)

1/ - المدخل إلى علم النفس/ محيي الدين توق وعبد الرحمن عدس، دار الفكر - عمّان، طه ،

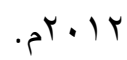
9 ا - المذاهب الوجودىة من كىر كجورد إلى جون بول سارنز اريجيس جوليفيه كترجمة

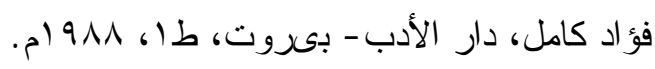

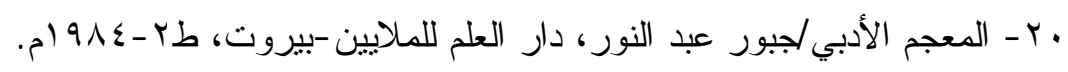

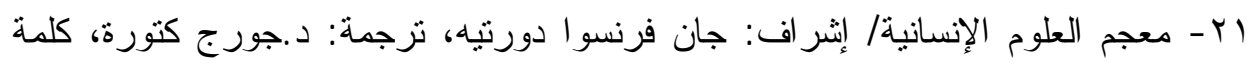

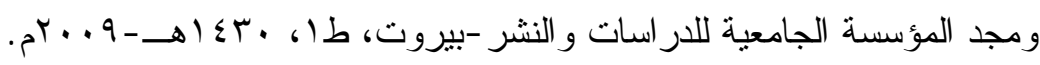

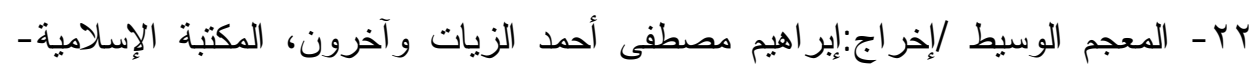

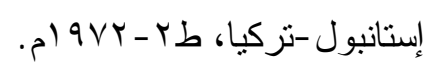
بr - نظريات الثخصية لجارندر لندزي -كالفن هول، نرجمة: فرج أحمد فرج، قدري

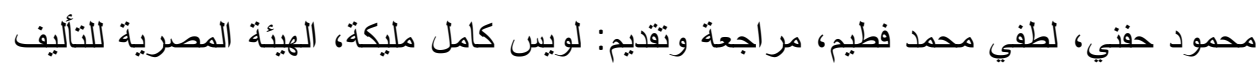

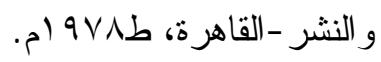
ع Y - وجه نرسيس في مياه الثعر :قصائد المرايا في تجربة أدونيس/حاتم صكر، مجلة

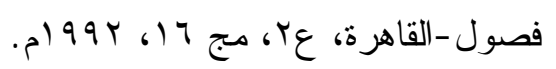

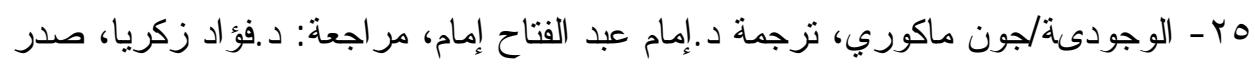

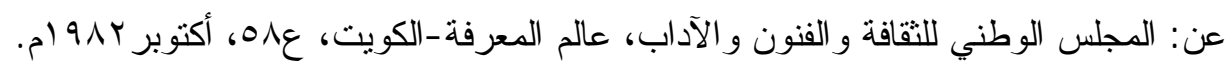
- مراجع إلكترونية: جب -مقال : (المر آة) /عدد من الكتاب : العريس، شوقي بزيع، نجاح طلعت، دارين صالح،

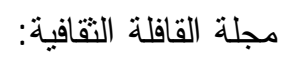
http://qafilah.com/ar/ 


\section{من ملامج الذاتوصورة الآخر في نماذج من شعر (زاهي وهبي) دكتورة/ أمل عبل الله زين العابلين}

V r مقال : (آلية المر آة في الشعر الفلسطيني المعاصر : محمد حسيب القاضي أنموذجاً)/ تقديم

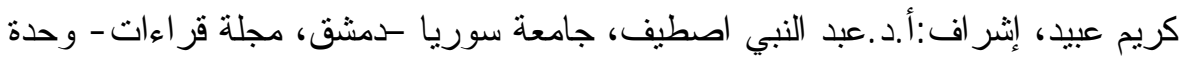

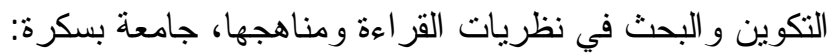
http://lab.univ- biskra.dz/Labreception/images/pdf/quiraeto/1 • .pdf

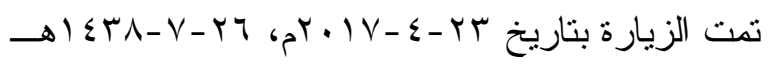

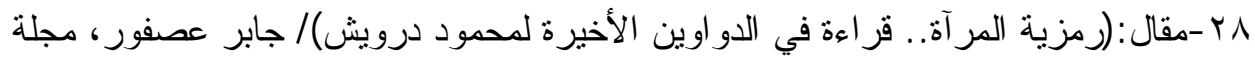

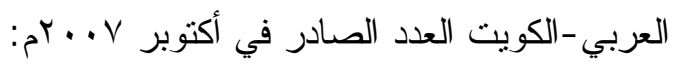
http://www.arabicstory. net/forum/index. php?showtopic=9 I 1 r

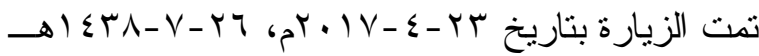
q باء مع زاهي وهبي في مجلة زهرة بعنوان (أضاهي المر أة أنوثة): http://www.anazahra.com/l $\leq 7 / r$

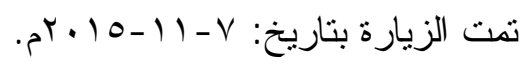

• r مقال :(تتكلات الأنا والآخر في شعر : نادر هدى) / د.طلاد الطاهر قطبي: www.alrai.com/print.html

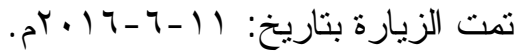

$$
\begin{aligned}
& \text { اب ويكيبيديا (الموسوعة الحرة): }
\end{aligned}
$$

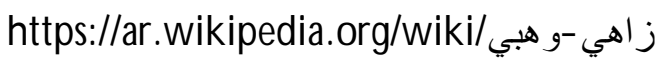

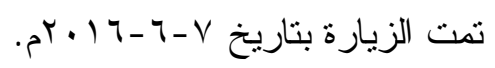

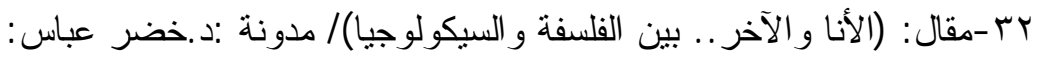
https://drabbass. wordpress.com/r.1r/.1/1T/

$$
\text { تمت الزيارة بتاريخ (1) -7 -7 } 11 \text { - مبم. }
$$

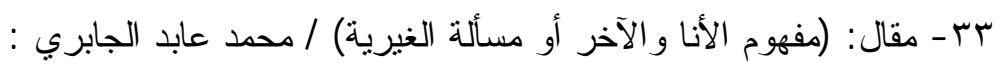

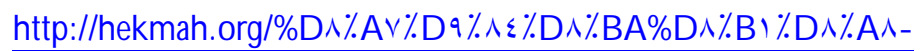

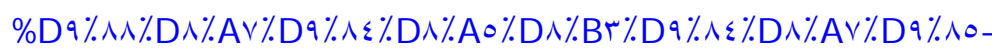

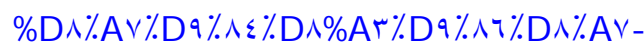
\%D $\% \% \wedge \wedge \% D \wedge \% A \vee \% D q \% \wedge \varepsilon \% D \wedge \% A r \% D \wedge \% A E \% D \wedge \% B$ -

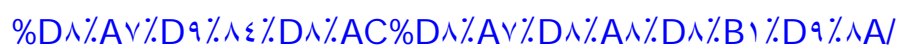


